\title{
The Source of Ore Fluids and Sm-Nd Age of Siderite from the Largest Bakal Deposit, Southern Urals
}

\author{
M. T. Krupenin ${ }^{a, *}$, A. B. Kuznetsov ${ }^{b, * *}$, M. V. Chervyakovskaya ${ }^{a}$, \\ T. Ya. Gulyaeva ${ }^{a}$, and G. V. Konstantinova ${ }^{b}$ \\ ${ }^{a}$ Zavaritskii Institute of Geology and Geochemistry, Ural Branch, Russian Academy of Sciences, Yekaterinburg, 620016 Russia \\ ${ }^{b}$ Institute of Precambrian Geology and Geochronology, Russian Academy of Sciences, St. Petersburg, 199034 Russia \\ *e-mail: krupenin@igg.uran.ru \\ **e-mail: antonbor9@mail.ru
}

Received March 12, 2021; revised April 5, 2021; accepted April 14, 2021

\begin{abstract}
Based on Sm-Nd data, a crustal source of iron-ore fluid was substantiated and the probability of age estimation for hydrothermal-metasomatic siderite of the Bakal Group, Southern Urals, was shown for the first time. The $\varepsilon \mathrm{Nd}(\mathrm{T})$ values of siderite (from -13.4 to -17.6) plot in the field of Riphean shale and not the Precambrian rift gabbro and granite of this region. The obtained $\mathrm{Sm}-\mathrm{Nd}$ age of the Bakal siderite is 970 $\pm 40 \mathrm{Ma}$, which is consistent with the $\mathrm{Pb}-\mathrm{Pb}$ age of siderite from the major ore phase $(\sim 1000 \mathrm{Ma})$. The established age boundary coincides with tectonic restructuring, including the formation of a number of baritepolymetallic deposits, as well as ferruginous magnesite and fluorite in the Riphean deposits on the western slope of the Southern Urals.
\end{abstract}

Keywords: Sm and Nd isotopes, siderite, metasomatism, Riphean, Bakal ore field

DOI: $10.1134 / \mathrm{S} 1075701521040048$

\section{INTRODUCTION}

The geological study of the Bakal siderite deposits, which are a typical object of siderite hydrothermalmetasomatic deposits in sedimentary carbonate rocks (Smirnov, 1976), is considered in a huge number of papers and of monographs (Yanitskii and Sergeev, 1962; Timeskov, 1963; Varlakov, 1967; Anfimov et al., 1984; Krupenin, 1999; Kuznetsov et al., 2005; Kholodov and Butuzova, 2008; Krupenin, 2017). The group of Bakal iron deposits in the Southern Urals is a convenient testing ground for solving the problem of the genesis of iron ore formations in Precambrian sedimentary rocks. In explored reserves (more than $1.2 \mathrm{bln} \mathrm{t}$, Yanitskiy and Sergeev, 1962) and production volume, the Bakal ore field is on par with the well-known siderite giants, such as Erzberg in Austria, Bilbao in Spain, and Quenza in Algeria (Pohl et al., 1986; Frimmel, 1988).

The Bakal deposits have been mined for more than 250 years, since Demidov's time. The long-term controversy about the genesis of Riphean siderite in the Urals during the 20th century ruled out the idea of D.V. Nalivkin (1931) and his supporters (Malakhov, 1957; Druzhinin, 1971; Borshchevskii et al., 1978; Dunaev, 1983) on the lagoonal origin of layered bodies. The set of features makes it possible to classify these ore deposits as hydrothermal-metasomatic (Zavaritskii, 1939; Davydenko, 1956; Yanitskii and
Sergeev, 1962; Anfimov, 1997; Krupenin, 1999, etc.). The source of ore fluids remains controversial. A.N. Zavaritskii (1939) and his followers (Yanitskii and Sergeev, 1962; Timeskov, 1963; Varlakov, 1967; etc.) suggested the removal of iron from the magma chamber after large-scale intrusion of gabbroids (doleritic dikes of the Bakal syncline up to $200 \mathrm{~m}$ thick; the Kusa-Kopan intrusion with a length of up to $90 \mathrm{~km}$ ) and granitoids (Berdyaush and Ryabinov massifs) (Timeskov, 1963). The ore-forming process was associated with the Paleozoic Uralian orogen. Later L.V. Anfimov proposed a catagenetic source of iron mobilized by elision solutions from the host shale rocks in the Riphean (Anfimov et al., 1984; Anfimov, 1997), while V.N. Kholodov suggested the input of iron into sedimentary strata from Early Precambrian ferruginous quartzite of the crystalline basement (Kholodov and Butuzova, 2008). According to a study of the $\mathrm{Pb}-\mathrm{Pb}$ systematics, the age of siderite mineralization was estimated as $1010 \pm 100 \mathrm{Ma}$ (Kuznetsov et al., 2005). It is suggested that ore formation is associated with the migration of iron-bearing solutions upsection into carbonate reservoirs along decompaction zones and faults at the tectonic activation stage at the Middle-Late Riphean boundary. As evident from the $\mathrm{Rb}-\mathrm{Sr}$ systematics of carbonate rocks and ores (Kuznetsov et al., 2005), ore solutions interacted with shale of the sedimentary basin. Chromatographic 
study of the composition of fluid inclusions, as well as carbon, hydrogen, and oxygen stable isotopes in siderite and host carbonate rocks, has demonstrated the important role of buried brines for the fluid formation in the catagenetic basin (Prochaska and Krupenin, 2013).

This paper presents the results of a study of the $\mathrm{Sm}-\mathrm{Nd}$ isotopic systematics of siderite and host carbonate rocks of the Bakal ore field for the first time, showing the probability of using these data to determine the source of iron ore fluid and to refine the age of metasomatic siderite.

\section{GEOLOGY OF THE DEPOSITS}

The world's largest accumulation of siderite iron ores (Bakal deposits, Bakal ore field) is located on the western slope of the Southern Urals and is confined to Lower Riphean carbonate-terrigenous deposits, which formed as a part of the Upper Precambrian sedimentary sequence within the Cis-Uralian pericratonic depression the of eastern part of the continent Baltica (Puchkov, 2010). A thick (more than $15 \mathrm{~km}$ ) sequence of volcanosedimentary deposits accumulated there over more than $1 \mathrm{Ga}(1750-640 \mathrm{Ma})$. In the Vendian and Late Paleozoic, the Riphean sedimentary rocks of the eastern part of the Cis-Uralian pericratonic depression were involved in fold zones and became part of the Uralian Orogen, forming the Bashkir Meganticlinorium (BMA), which is a large structure within the Central Ural Uplift.

The modern erosion level in the structure of the BMA makes it possible to study the section of typical Riphean sediments (Stratotip rifeya, 1982; Maslov et al., 2001; Semikhatov et al., 2009, 2015). It includes four strats (Fig. 1): lower (Burzyanian, 1750$1400 \mathrm{Ma}$ ), middle (Yurmatinian, 1400-1030 $\pm 30 \mathrm{Ma}$ ), upper (Karatavian, $1030 \pm 30-770 \mathrm{Ma}$ ), and end (Arshinian, 770-640 Ma) (Puchkov, 2010; Puchkov et al., 2017). The Vendian sediments overlying the Riphean rocks in the composition of tillites and terrigenous Asha Group were deposited 640-548 Ma (Grazhdankin et al., 2011; Zaitseva et al., 2019). The Riphean series has a regular structure with a coarseclastic base and terrigenous-carbonate fill in the middle and upper parts. In addition, the Burzyanian and Yurmatinian rocks contain rift volcanics at the base (Ai and Mashak formations, respectively); the Arshinian volcanic rocks are confined to the middle part of the terrigenous section (Igonin Formation). A number of anticlinoria and synclinoria with a northeastern strike are distinguished in the tectonic structure of the BMA; the boundaries between them are complicated by thrusts and upthrusts. Burzyanian deposits of the Ai Formation overlie $\mathrm{AR}-\mathrm{PR}_{1}$ crystalline schist and gneiss of the Taratash Complex in the northern part of the BMA (Taratash Anticlinorium). Igneous formations in the BMA are mainly confined to the zone of the Mashak rift east of the Zyuratkul-Karatash Thrust and are represented by both volcanic rocks (trachybasalt and trachyrhyolite of the Mashak Formation) and more widespread dike swarms in the Burzyanian deposits, a submeridional Kusa gabbroid intrusion consisting of several massifs up to $90 \mathrm{~km}$ long, as well as associated plagiogranite (Guben and Ryabinov massifs), and the Berdyaush Pluton of rapakivi granite (Ernst et al., 2006; Kholodnov et al., 2010; Larin, 2011). The volcanic rocks of the Mashak Formation are observed in the eastern part of the BMA from north to south at a distance of up to $200 \mathrm{~km}$, forming a linear rift complex together with dike swarms in sedimentary rocks and intrusive bodies of Kusa gabbroid and granitoid rocks (Parnachev et al., 1986, etc.).

Siderite is associated with Burzyanian deposits (Lower Riphean): the Bakal ore field (near the city of Bakal) in the Bakal Formation and Akhta deposit (20 km east of the city of Kusa) in the Satka Formation. Magnesite of the South Ural Province, including the Satka deposits, the largest in Russia (Krupenin and Kol'tsov, 2017), as well as a number of deposits of polymetals, barite, and fluorite, are associated with Burzyanian and Yurmatinian carbonate deposits. Riphean rocks are altered at the deep catagenesis level, while in the eastern part of the BMA, east of the Zyuratkul'-Karatash Thrust, at the metagenesis and greenschist metamorphism level (Anfimov, 1997).

The Bakal ore field is located in the northern part of the BMA (the southern periclinal closure of the Taratash Anticlinorium, see Fig. 1) and is confined to the Bakal Syncline, which gently dips to the southwest. The ore-bearing Lower Riphean terrigenouscarbonate Bakal Formation (1400 m) consists of two subformations: the lower (Makarov), with an essentially terrigenous-shale composition, and the upper (Malobakal), consisting of alternating carbonate and terrigenous-shale members with a total thickness of up to $900 \mathrm{~m}$. The Bakal Formation is comformably underlain by carbonate rocks of the Satka Formation $(1550 \pm 30 \mathrm{Ma}$, Kuznetsov et al., 2008) and unconformably overlain by Middle Riphean quartzite-like

Fig. 1. Geological sketch map of Bashkir Meganticlinorium (BMA), after (Puchkov, 2010). (1) Vendian; (2) Upper Riphean, Arshinian Group; (3) Upper Riphean, Karatavian Group; (4-6) Middle Riphean: (4) undissected, (5) Zigal'ga Formation, (6) Mashak Formation; (7-9) Lower Riphean: (7) Bakal and Yusha formations, (8) Satka and Suran formations, (9) Ai and Bol'sheinzer formations; (10) Archean and Early Proterozoic (metamorphic rocks of Taratash Complex); (11) metamorphic rocks of Ural-Tau Zone; (12) magmatic formations: (a) granitoids, (b) gabbroids; (13) geological boundaries; (14) faults; (15) major thrusts; (16) Paleozoic deposits. Inset at top shows position of Uralian Orogen on map of Russia and its schematic structure. Structural megazones from west to east: Uralian Trough, West Uralian, Middle Uralian (including BMA), Tagil-Magnitogorsk, and East Uralian. Dashed rectangle in vicinity of Bakal shows contour of Bakal ore field. 


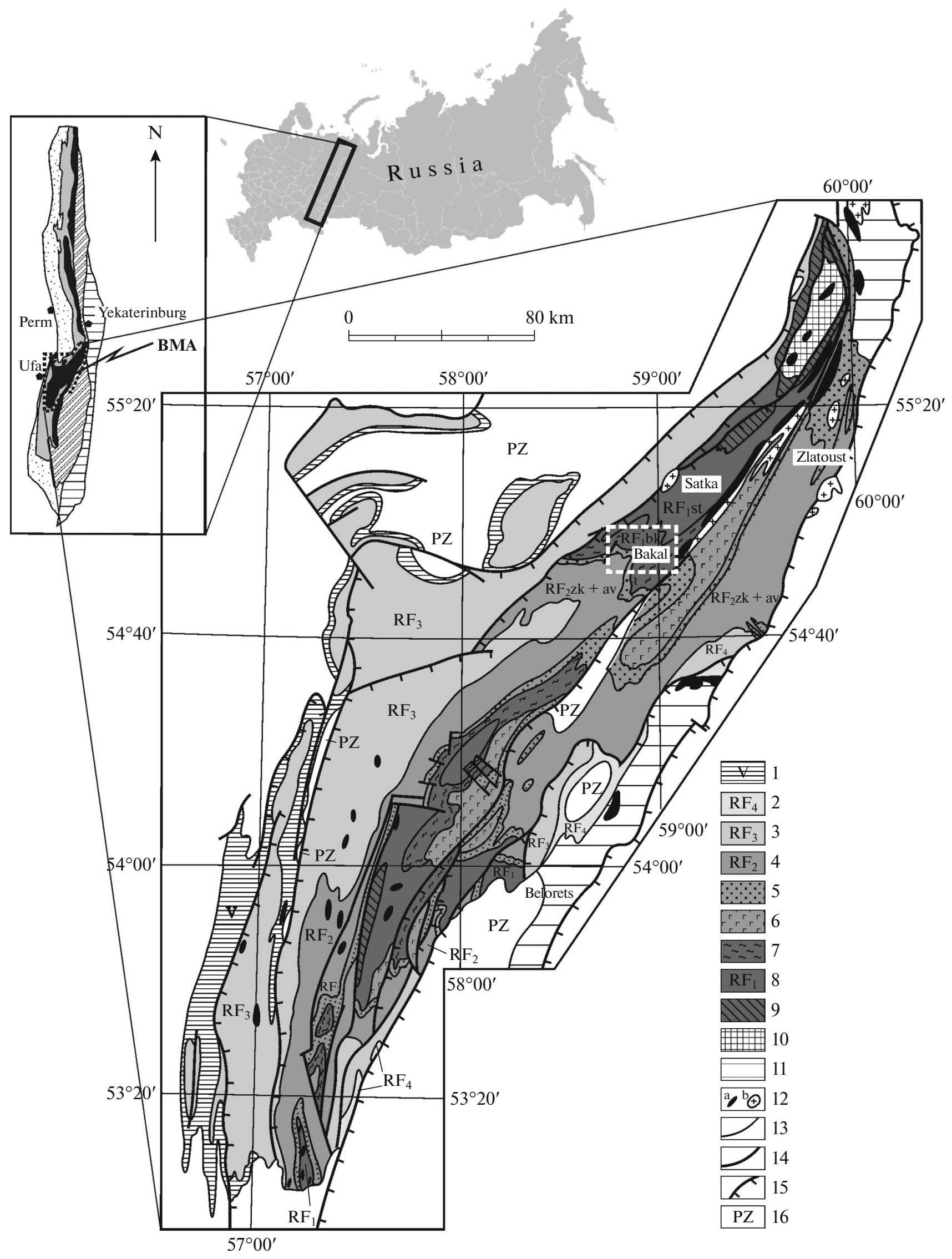



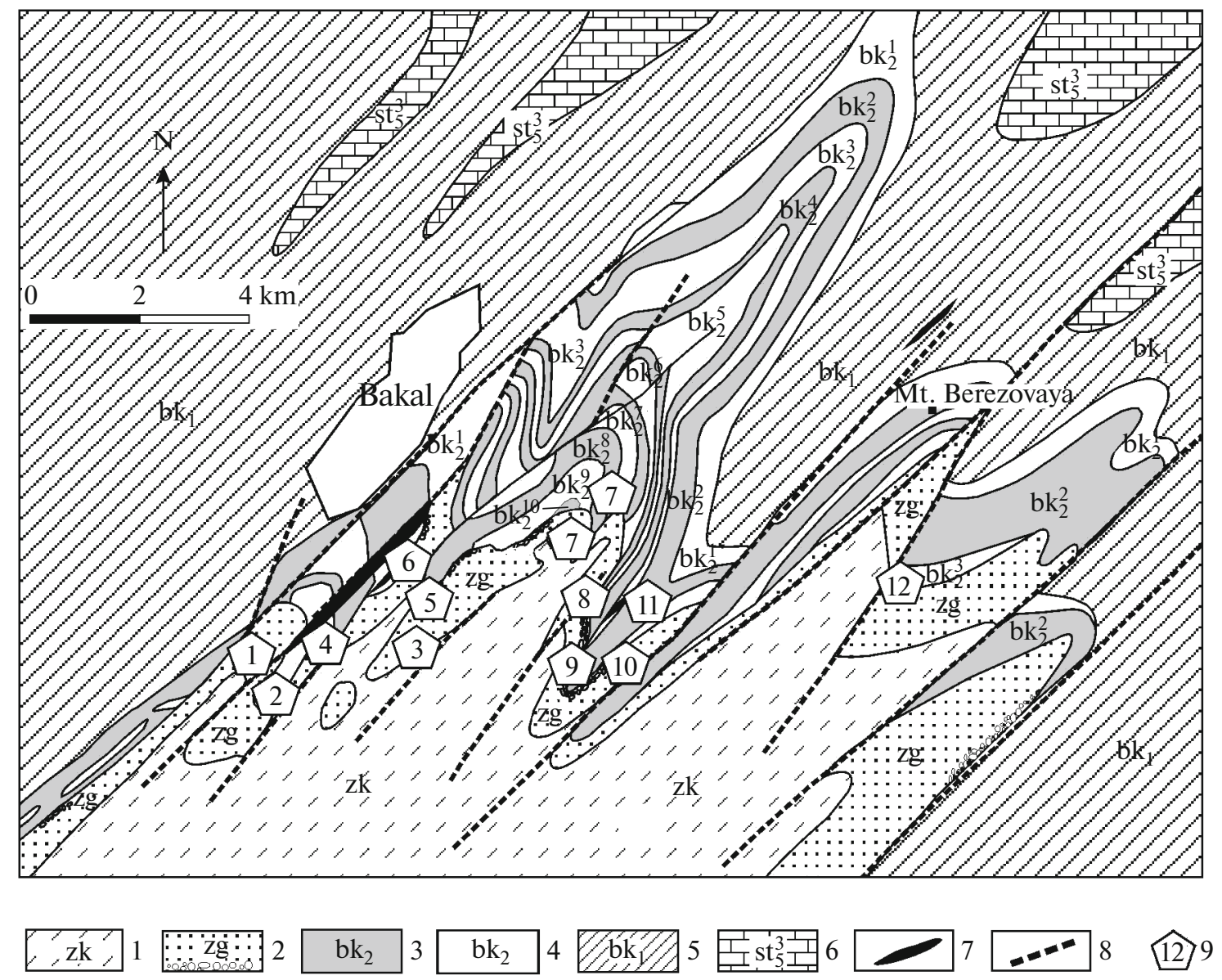

Fig. 2. Geological sketch map of Bakal ore field, modified after (Yanitskii and Sergeev, 1962). (1-2) Yurmatinian formations $\left(\mathrm{RF}_{2}\right)$ : (1) Zigazino-Komarov $\left(\mathrm{RF}_{2} \mathrm{zk}\right)$, (2) Zigal'g $\left(\mathrm{RF}_{2} \mathrm{zg}\right)$; (3-6) Burzyanian formations $\left(\mathrm{RF}_{1}\right)$ : (3-5) Bakal $\left(\mathrm{RF}_{1} \mathrm{bk}\right)$ : (3) Malobakal Subformation, terrigenous units $\left(\mathrm{RF}_{1} \mathrm{bk}_{2}^{2,4,6,8,10}\right),(4)$ Malobakal Subformation, carbonate units $\left(\mathrm{RF}_{1} \mathrm{bk}_{2}^{1,3,5,7,9}\right),(5)$ Makarov Subformation $\left(\mathrm{RF}_{1} \mathrm{bk}_{1}\right)$; (6) Satka, limestone and dolomite $\left(\mathrm{RF}_{1} \mathrm{st}_{5}^{3}\right)$; (7) dike of gabbro-dolerite; (8) major faults; (9) siderite deposits: (1) Petlinskoe, (2) Im. OGPU, (3) Sideritovaya Mine (Rudnichnoe), (4) Sideritovyi, no. 5, (5) Kvartsitovoe, (6) Novobakal'skoe, (7) Vostochno-Bulandikhinskoe, (8) Tsentral'nyi Irkuskan, (9) Gaevskoe, (10) Aleksandrovskoe, (11) Okhryanye Yamy, (12) Malosukinskoe.

sandstone of the Zigal'ga Formation and silty shale of the Zigazino-Komarov Formation (Fig. 2). The age of limestone of the Bakal Formation is $1430 \pm 30 \mathrm{Ma}$ (Kuznetsov et al., 2003), and sedimentary phosphorite from the overlying Zigazino-Komarov Formation has an age of $1330 \pm 30 \mathrm{Ma}$ (Ovchinnikova et al., 2013). The deposits of the Bakal Formation are intruded by a series of doleritic dikes, including the thick $(>100 \mathrm{~m})$ Glavnaya Dike, with an age of $1384 \pm 1.5 \mathrm{Ma}$ (Ernst et al., 2006), in the western part of the ore field (between the Petlinskoe and Novobakal'skoe deposits), comagmatic to the Mashak rift event at the beginning of Yurmatinian ( $1380 \mathrm{Ma})$.

The sediments of the Zigal'ga Formation are underlain by the volcanogenic-terrigenous Mashak Formation with a thickness of up to $3 \mathrm{~km}$ to the east from the Bakal ore field and the regional Zyuratkul'Karatash Fault traced by the Kusa Intrusion in the
Taganaisko-Iremel'skii Anticlinorium. The age of Mashak rhyodacite is $1383 \pm 3 \mathrm{Ma}$ (Krasnobaev et al., 2013). Thus, the Bakal ore field is located on the western side of the Mashak rift.

Orebodies are localized in five carbonate members of the Malobakal'skaya Subformation (from bottom to top): Berezov $\left(\mathrm{RF}_{1} \mathrm{bk}_{2}^{1}\right)$, Shuida $\left(\mathrm{RF}_{1} \mathrm{bk}_{2}^{3}\right)$, Gaev $\left(\mathrm{RF}_{1} \mathrm{bk}_{2}^{5}\right)$, Shikhan $\left(\mathrm{RF}_{1} \mathrm{bk}_{2}^{7}\right)$, and Verkhnebakal $\left(\mathrm{RF}_{1} \mathrm{bk}_{2}^{9}\right)$. The thickness of carbonate units varies within $60-250 \mathrm{~m}$. The siderite deposits are mainly located near the contact of carbonate units with unconformably overlying quartzite sandstone of the Zigal'gina Formation and form a sublatitudinal zone up to $10 \mathrm{~km}$ in length (from the Petlinskoe deposit in the west to the Malosukinskoe deposit in the east, see Fig. 2). The depth of the Prezigal'ga erosion of depos- 
its of the Malobakal Subformation is up to $700 \mathrm{~m}$. The ore field is complicated by folds of different orders and is intersected by numerous upthrusts and shears with an amplitude of up to $500 \mathrm{~m}$ and a prevailing SW-NE orientation (more than 20), serving as natural boundaries of individual deposits (Yanitskii and Sergeev, 1962). A multi-level structure of ore deposits is observed near the steeply dipping faults: mineralization occurs in 2-3 units below the surface of stratigraphic unconformity within a single deposit. For example, this is typical for the Shikhanskoe and Rudnichnoe deposits developed by the mines, as well as the Irkuskan and Novobakal'skii quarries. Thus, steeply dipping faults are the ore-supplying zone, while the surface of the interformational Prezigal'ga unconformity is an ore-distributing zone (Yanitskii and Sergeev, 1962; Krupenin, 1999, 2017).

Large siderite deposits have a sheetlike shape; their thickness reaches tens of meters, and the length is hundreds of meters along strike. The smaller bodies are pocket- and stocklike. Some bedlike deposits reach a length of $2-3 \mathrm{~km}$; their maximum thickness is determined by the thickness of the ore-bearing carbonate unit and may reach $80 \mathrm{~m}$ (Shikhanskoe Deposit, Berezov Unit, Irkuskanskoe Deposit, and Gaev Unit). All orebodies have much evidence for superimposed formation after sedimentary carbonate rocks: the boundaries of siderite bodies intersect elements of layering and stromatolite textures. Siderite intersects the crystalline magnesite deposits occurring in the Shuyda Unit $\left(\mathrm{RF}_{1} \mathrm{~b}_{2}{ }^{3}\right)$ with an age of $\sim 1370 \mathrm{Ma}$ (Ovchinnikova et al., 2018). Dolomite relics have been recorded in siderite bodies; there are the signs of prefold ore formation; siderite pinches out near marble formation zones, at the contacts with large doleritic dikes and sills; less frequently, sideritization of mafic dikes with preservation of ophitic texture is observed. In addition, there have been observations of individual postore doleritic dikes that intersect preore dikes and form an exomorphic contact zone of finely disseminated magnetite up to $1 \mathrm{~m}$ thick in siderites (Krupenin, 1999).

Siderite deposits in limestone always occur in a thin zone of ankerite and a wide environ of $\mathrm{Fe}$-dolomite; dolomite relics are observed in siderite bodies. Large siderite deposits are composed of monomineral sideroplesite containing $>30 \% \mathrm{FeO}$; up to $3-12 \%$ $\mathrm{MgO}, 1.5-2 \% \mathrm{MnO}$, and up to $1.5-2 \% \mathrm{CaO}$ are registered in the form of isomorphic impurities. Bi- and polymineral ores predominate on the flanks of large deposits and in the small bodies: sideroplesites with an admixture of dolomite-ankerite and even calcite (Timeskov, 1963). According to the huge microprobe data obtained for ten different localities in the western and central parts of the Bakal ore field, the contact ankerite shows variations in the average $\mathrm{FeCO}_{3}$ concentrations of 14.2 and $20.8 \mathrm{wt} \%$, respectively (Krupenin, 2017). At the same time, no pronounced differ- ences were detected in the composition of the contact sideroplesite in the same objects; the content of the $\mathrm{FeCO}_{3}$ end-member varies in the range of 67.8$80.4 \mathrm{wt} \%$. Considering the huge scale of hydrothermal metasomatism in the Bakal area, we may assume that the mineral formation was of an equilibrium character. The use of the ankerite-siderite (Annovitz and Essene, 1987) and ankerite-breinerite (Martynov, 1990) geothermometers for the study of the temperature limits of metasomatism showed that the temperature of sideroplesite formation did not depend on the position of the ore deposit in the stratigraphic section of the Bakal Formation, but is determined by the position in the structure of the Bakal ore field. The average calculated temperatures of metasomatism in the middle part (Vostochno-Bulandikhinsky and Irkuskan quarries) are $250-270^{\circ} \mathrm{C}$, while in the peripheral western part (Novobakalskii quarry) they do not exceed $190-220^{\circ} \mathrm{C}$ (Krupenin, 2017).

The content of most of trace elements in siderite is at the clarke level. The ores do not contain the high concentrations of elements indicating a link to igneous mafic or felsic rocks (Ellmies et al., 1999). The higher contents in siderite relative to host dolomite are detected for $\mathrm{Ba}$ (the average contents are 59 and $23 \mathrm{ppm}$, respectively), $\mathrm{Rb}$ (1.98 and 0.32 ), and $\mathrm{Cs}$ ( 0.22 and 0.08 ); the lower contents, for $\mathrm{Sr}$ (12 and 34; in limestone they increase to $2000 \mathrm{ppm}$ ). The REE distribution in siderite differs from that in the host carbonate rocks. Chondrite-normalized spectra of the host carbonate rocks, free of terrigenous-shale admixtures, show a gradual decrease in the concentrations from La to Lu (Fig. 3, curves 1 and 2). In siderite the trend changes to the opposite with a gradual increase in the concentration from La to Lu (see Fig. 3, curve 3 ), which supports the mineralogical control, since the ionic radius of $\mathrm{Fe}^{2+}$ is closer to that of $\mathrm{Lu}$ than of La. The depletion of siderite in LREEs is a favorable factor for the accumulation of samarium (an incoherent element) relative to neodymium. Shale carbonates (Fig. 3, curves 4 and 5) demonstrate the same tendency towards decrease in $\mathrm{La} / \mathrm{Yb}$ is observed in the limestone-dolomite-siderite series, but in the latter, a subhorizontal distribution of REE is observed (Fig. 3, curve 6).

\section{RESEARCH METHODS}

The experience in studying Riphean siderite using microprobe analysis and $\mathrm{Rb}-\mathrm{Sr}$ and $\mathrm{U}-\mathrm{Pb}$ isotopic studies showed that the most complete metasomatic alteration occurred in large bodies within the central part of the Bakal ore field (Kuznetsov et al., 2005; Krupenin, 2017). Therefore, we selected mainly orebodies in the center of the ore field for the $\mathrm{Sm}-\mathrm{Nd}$ systematics: in the Shuida and Gaev units in the Irkuskan quarry and in the Verkhnebakal unit in the Vostochno-Bulandikhinskii quarry. Siderite, dolo- 


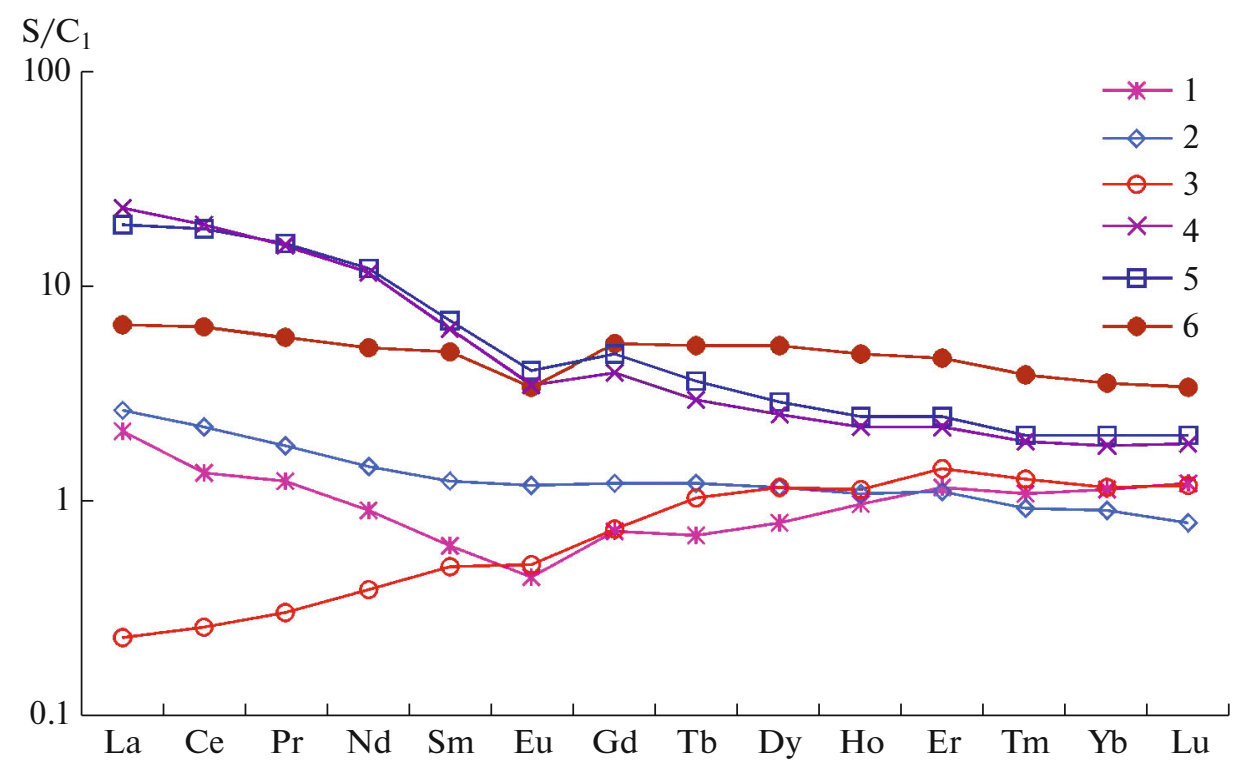

Fig. 3. Chondrite-normalized REE distribution in pure (1-3) and clayey (4-6) carbonate rocks. (1) Limestone $B-2\left(R_{1} b_{2}^{1}\right.$, Berezov Unit, Mt Berezovaya); (2) dolomite A-2 $\left(\mathrm{RF}_{1} \mathrm{bk}_{2}^{3}\right.$, Shuida Unit, Irkuskan quarry); (3) siderite Kont-1-1 (RF $\mathrm{bk}_{2}^{3}$,

Shuida Unit, Irkuskan quarry); (4) limestone X-12; (5) dolomite X-10; (6) siderite X-4 ( $\mathrm{RF}_{1} \mathrm{bk}_{2}^{5}$, Gaev Unit, Irkuskan quarry).

Sample nos. are same as in Fig. 4.

mites in exomorphic contacts, and limestone were studied (Table 1).

At the first stage, field samples collected from the walls of quarries were subjected to comprehensive physicochemical study in order to identify the rocks purest from terrigenous admixtures and susceptible to sideritization processes. Chemical silicate analysis (X-ray fluorescence method, a SRM-35 spectrometer, Table 2), X-ray diffraction analysis (an XRD-7000 diffractometer, Shimadzu), and a study of the concentration of more than 40 trace elements, including REE (Perkin Elmer Elan-9000 ICP-MS) were performed at the Geoanalitik Collective Use Center, Yekaterinburg) using standard techniques. Some of the chemical analyses were obtained by X-ray fluorescence at the Berlin Technical University, Germany.

Selective dissolution of the carbonate component of the sample for isotope studies was carried out according to the methodology of (Kuznetsov et al., 2005; Ovchinnikova et al., 2018) in $1 \mathrm{~N} \mathrm{HCl}$ without heating. The $\mathrm{Nd}$ isotopic composition in the samples was measured on a Neptune Plus mass spectrometer by MC-ICP-MS (Geoanalitik Collective Use Center). The $\mathrm{Sr}$ isotopic composition of siderite from the Irkuskan deposit was measured on a Finnigan MAT 261 mass spectrometer (Institute of Precambrian Geology and Geochronology, Russian Academy of Sciences, St. Petersburg), while the other samples were measured on a Triton Plus mass spectrometer (Geoanalitik Collective Use Center). The uncertainty in measuring the ${ }^{147} \mathrm{Sm} /{ }^{144} \mathrm{Nd}$ ratio was $0.4 \%$;
${ }^{143} \mathrm{Nd} /{ }^{144} \mathrm{Nd},-0.01 \% ;{ }^{87} \mathrm{Rb} /{ }^{86} \mathrm{Sr}, 0.5 \%$; and ${ }^{87} \mathrm{Sr} /{ }^{86} \mathrm{Sr}$, $0.002 \%(2 \sigma)$. The average value in a standard Merck sample $\left(\mathrm{Nd}_{2} \mathrm{O}_{3}\right)$ during the operating period was $0.51172 \pm 0.00003(2 \sigma, n=3)$; for NIST SRM 987, $0.71026 \pm 0.00002(2 \sigma, n=3)$ at the Geoanalitik Collective Use Center and $0.71025+0.00001(2 \sigma, n=16)$ at the Institute of Precambrian Geology and Geochronology, Russian Academy of Sciences. Table 3 presents the data from studying the $\mathrm{Rb}-\mathrm{Sr}$ and $\mathrm{Sm}-$ $\mathrm{Nd}$ isotopic systematics.

\section{RESULTS}

In the central part of the ore field, the siderite deposits were studied in the Irkuskan and VostochnoBulandikhinskii quarries. Siderites on the northern flank of the Irkuskan quarry formed after limestone stromatolite bioherm in the Gaiev Unit: the pattern of metasomatic zoning of carbonates with stromatolite texture is clearly visible on the northern flank (Fig. 4a). All carbonate rocks contain an admixture $(2-10 \%)$ of quartz, hydromica, and chlorite. To study the $\mathrm{Sr}-\mathrm{Nd}$ isotope systematics, rock varieties purest from terrigenous admixtures were selected (Tables $1-3$, samples of the $\mathrm{X}-\ldots$ series). Siderite forms sheetlike bodies in the host shallowly bedded dolomite, which are practically devoid of terrigenous admixture in the stratigraphically lower Shuida Unit in this quarry (samples $\mathrm{K}-1 / 13$ and $\mathrm{K}-1 / 5)$; however, upsection, the content of terrigenous admixture in dolomite increases (sample A-2) and the siderite mineralization is poorer. 
Table 1. Mineral composition of carbonate rocks and ores, according to X-ray structural analysis data, wt $\%$

\begin{tabular}{|c|c|c|c|c|c|c|c|c|c|}
\hline Sample & Unit & Rock & Cal & Dol & $\mathrm{Sd}$ & Qtz & Chl & Ms & Py \\
\hline \multicolumn{10}{|c|}{ Novobakal'skii quarry } \\
\hline Y-7 & $\mathrm{RF}_{1} \mathrm{bk}_{2}^{1}$ & Dolomite & - & 98 & - & traces & - & traces & - \\
\hline$y-5^{*}$ & $\mathrm{RF}_{1} \mathrm{bk}_{2}^{1}$ & Siderite & - & traces & 97 & 2 & - & traces & traces \\
\hline \multicolumn{10}{|c|}{ Iruskanskii quarry } \\
\hline A-2 & $\mathrm{RF}_{1} \mathrm{bk}_{2}^{3}$ & Dolomite & - & 100 & traces & 3 & traces & - & - \\
\hline $\mathrm{K}-1 / 13$ & $\mathrm{RF}_{1} \mathrm{bk}_{2}^{3}$ & Dolomite & - & 100 & - & - & - & - & - \\
\hline $\mathrm{K}-1 / 5$ & $\mathrm{RF}_{1} \mathrm{bk}_{2}^{3}$ & Dolomite & - & 1 & 99 & - & - & - & - \\
\hline $\mathrm{x}-12$ & $\mathrm{RF}_{1} \mathrm{bk}_{2}^{5}$ & Limestone & 90 & 7 & - & 2 & traces & traces & - \\
\hline$x-10$ & $\mathrm{RF}_{1} \mathrm{bk}_{2}^{5}$ & Dolomite & - & 92 & - & 3 & traces & 1 & - \\
\hline $\mathrm{x}-7^{*}$ & $\mathrm{RF}_{1} \mathrm{bk}_{2}^{5}$ & Siderite & - & 2 & 95 & 1 & - & traces & 2 \\
\hline$x-5$ & $\mathrm{RF}_{1} \mathrm{bk}_{2}^{5}$ & Siderite & - & 1 & 96 & 2 & - & traces & 1 \\
\hline$x-4^{*}$ & $\mathrm{RF}_{1} \mathrm{bk}_{2}^{5}$ & Siderite & - & - & 98 & traces & - & traces & - \\
\hline $\mathrm{x}-3^{*}$ & $\mathrm{RF}_{1} \mathrm{bk}_{2}^{5}$ & Siderite & - & - & 98 & traces & - & traces & - \\
\hline \multicolumn{10}{|c|}{ Vostochno-Bulandikhinskii quarry } \\
\hline $453-1$ & $\mathrm{RF}_{1} \mathrm{bk}_{2}^{9}$ & Siderite & - & - & 100 & - & - & - & - \\
\hline Bul-4 & $\mathrm{RF}_{1} \mathrm{bk}_{2}^{9}$ & Siderite & - & 5 & 95 & - & - & - & - \\
\hline $17-S-2$ & $\mathrm{RF}_{1} \mathrm{bk}_{2}^{9}$ & Siderite & - & 7 & 87 & 6 & - & - & - \\
\hline $17-S-3$ & $\mathrm{RF}_{1} \mathrm{bk}_{2}^{9}$ & Siderite & - & 2 & 94 & 4 & - & - & - \\
\hline $17-S-4$ & $\mathrm{RF}_{1} \mathrm{bk}_{2}^{9}$ & Siderite & - & - & 95 & 5 & - & - & - \\
\hline $17-S-5$ & $\mathrm{RF}_{1} \mathrm{bk}_{2}^{9}$ & Siderite & - & - & 95 & 5 & - & - & traces \\
\hline $17-S-6$ & $\mathrm{RF}_{1} \mathrm{bk}_{2}^{9}$ & Siderite & - & - & 88 & 5 & 5 & traces & 2 \\
\hline $17-S-7$ & $\mathrm{RF}_{1} \mathrm{bk}_{2}^{9}$ & Siderite & - & - & 95 & 5 & - & - & - \\
\hline
\end{tabular}

Cal, calcite; Dol, dolomite; Sd, siderite; Qtz, quartz; Chl, chlorite; Ms, muscovite; Py, pyrite; units of Malo-Bakal Subformation: $\mathrm{RF}_{1} \mathrm{bk}_{2}^{1}$, Berezov; $\mathrm{RF}_{1} \mathrm{bk}_{2}^{3}$, Shuida; $\mathrm{RF}_{1} \mathrm{bk}_{2}^{5}, \mathrm{Gaev} ; \mathrm{RF}_{1} \mathrm{bk}_{2}^{9}$, Verkhne-Bakal.

Siderite samples with massive structures (453-1 and Bul-4) were collected in the Vostochno-Bulandikhinskii quarry (Fig. 4b) from a thick ore bed at the $750 \mathrm{~m}$ horizon. Six samples of siderite with a fine-layered structure (17-S-2 to 17-S-7) were taken from one stratigraphic layer at a distance of 1 to $9 \mathrm{~m}$ from the intersecting metasomatic contact with finely bedded dolomite at the $790 \mathrm{~m}$ horizon. No sedimentary limestones are known in this stratigraphic horizon. Siderite of this layer contains $3-6 \%$ of quartz and an insignificant admixture of hydromica, chlorite, and sometimes pyrite (up to $2 \%$ ). Near the contact, at a distance of up to $1.5 \mathrm{~m}$, siderite contains an admixture of dolomite, the content of which decreases deeper into the deposit from 7 to $2 \%$. Further from the endomorphic contact, the deposit is represented by monomineralic sideroplesite with a stable composition: $41.4-43.7 \% \mathrm{FeO}$, 8.8-9.4\% $\mathrm{MgO}, 1.6-1.9 \% \mathrm{MnO}$, and $0.28-0.69 \%$ $\mathrm{CaO}$ (Table 2).

For comparison, samples of siderite $(y-5)$ quite pure of the terrigenous-shale admixture and near-ore dolomite (y-7) were collected from the western part of the ore field (Novobakalskii quarry) in the Berezov Unit, at the base of the Malobakal Subformation. The rocks had a vein-lenticular structure due to the occurrence of secondary veins, which have a yellowish creamy color in siderite and grayish white in dolomite. As in other carbonate units, sideroplesites in these 
Table 2. Chemical composition of carbonate rocks and ores, according to data of X-ray phase analysis

\begin{tabular}{|c|c|c|c|c|c|c|c|c|c|c|c|c|c|}
\hline Sample & $\mathrm{SiO}_{2}$ & $\mathrm{TiO}_{2}$ & $\mathrm{Al}_{2} \mathrm{O}_{3}$ & $\mathrm{Fe}_{2} \mathrm{O}_{3}^{\text {tot }}$ & $\mathrm{MnO}$ & $\mathrm{MgO}$ & $\mathrm{CaO}$ & $\mathrm{Na}_{2} \mathrm{O}$ & $\mathrm{K}_{2} \mathrm{O}$ & $\mathrm{P}_{2} \mathrm{O}_{5}$ & $\mathrm{CO}_{2}$ & $\mathrm{H}_{2} \mathrm{O}+$ & Total \\
\hline \multicolumn{14}{|c|}{ Novobakal'skii quarry } \\
\hline Y-7* & 3.11 & 0.04 & 1.51 & 8.18 & 0.58 & 14.71 & 28.32 & $<0.1$ & 0.45 & 0.01 & \multicolumn{2}{|c|}{44.3} & 101.1 \\
\hline$y-5^{*}$ & 4.82 & 0.03 & 1.38 & 36.51 & 1.02 & 16.28 & 0.78 & $<0.1$ & 0.36 & 0.03 & \multicolumn{2}{|c|}{40.73} & 101.9 \\
\hline \multicolumn{14}{|c|}{ Irkuskan quarry } \\
\hline A-2* & 6.24 & 0.05 & 1.21 & 1.68 & 0.07 & 16.85 & 27.1 & $<0.01$ & 0.66 & 0.11 & \multicolumn{2}{|c|}{43.56} & 97.5 \\
\hline $\mathrm{X}-12^{*}$ & 3.14 & 0.03 & 0.92 & 0.56 & 0.04 & 0.65 & 50.78 & $<0.1$ & 0.25 & 0.03 & 43.34 & 0.29 & 100.0 \\
\hline $\mathrm{X}-10^{*}$ & 5.61 & 0.03 & 0.95 & 4.46 & 0.32 & 16.80 & 27.59 & $<0.1$ & 0.31 & 0.01 & 44.92 & 0.33 & 101.3 \\
\hline $\mathrm{X}-7^{*}$ & 2.94 & 0.03 & 0.95 & 45.20 & 2.87 & 9.51 & 0.73 & $<0.1$ & 0.34 & 0.02 & 40.34 & 0.30 & 103.2 \\
\hline $\mathrm{X}-5^{*}$ & 4.04 & 0.04 & 1.16 & 45.42 & 2.82 & 9.55 & 0.55 & $<0.1$ & 0.42 & 0.01 & 39.28 & 0.37 & 103.7 \\
\hline $\mathrm{X}-4^{*}$ & 3.52 & 0.03 & 0.89 & 46.46 & 2.75 & 8.38 & 0.82 & $<0.1$ & 0.32 & 0.02 & 39.39 & 0.31 & 102.9 \\
\hline $\mathrm{X}-3^{*}$ & 3.40 & 0.03 & 1.04 & 45.56 & 2.58 & 9.30 & 0.58 & $<0.1$ & 0.36 & 0.01 & 39.20 & 0.40 & 102.4 \\
\hline \multicolumn{14}{|c|}{ Vostochno-Bulandikhinskii quarry } \\
\hline $453-1$ & 2.19 & 0.030 & 1.14 & 52.59 & 1.848 & 7.67 & 0.41 & 0.06 & 0.15 & 0.010 & \multicolumn{2}{|c|}{33.77} & 99.9 \\
\hline Bul-4 & 7.08 & 0.000 & 0.37 & 42.60 & 1.030 & 11.70 & 4.19 & 0.07 & 0.01 & 0.003 & \multicolumn{2}{|c|}{32.80} & 99.8 \\
\hline $17-\mathrm{S}-2$ & 7.07 & 0.016 & 1.21 & 44.05 & 1.028 & 11.56 & 1.32 & 0.07 & 0.13 & 0.022 & \multicolumn{2}{|c|}{33.49} & 99.9 \\
\hline $17-S-3$ & 8.92 & 0.024 & 1.53 & 42.62 & 1.573 & 11.15 & 1.88 & 0.06 & 0.18 & 0.019 & \multicolumn{2}{|c|}{31.90} & 99.8 \\
\hline $17-S-4$ & 6.17 & 0.069 & 2.63 & 46.50 & 1.924 & 9.08 & 0.43 & 0.07 & 0.37 & 0.012 & \multicolumn{2}{|c|}{32.67} & 99.9 \\
\hline $17-S-5$ & 4.51 & 0.030 & 1.35 & 47.89 & 1.883 & 9.44 & 0.68 & 0.07 & 0.18 & 0.014 & \multicolumn{2}{|c|}{33.77} & 99.8 \\
\hline $17-S-6$ & 6.36 & 0.073 & 2.95 & 46.00 & 1.590 & 9.24 & 0.69 & 0.07 & 0.45 & 0.010 & \multicolumn{2}{|c|}{32.49} & 99.9 \\
\hline $17-S-7$ & 7.75 & 0.066 & 2.94 & 45.76 & 1.709 & 8.80 & 0.32 & 0.07 & 0.39 & 0.016 & \multicolumn{2}{|c|}{31.97} & 99.8 \\
\hline
\end{tabular}

* Analyses were performed at Technical University of Berlin, Germany.

rocks contain minor admixtures of quartz, dolomite, muscovite, and pyrite.

All of the studied siderites have very low contents of $\mathrm{Sr}(2-3 \mathrm{ppm})$ and $\mathrm{Rb}(0.2-1.46 \mathrm{ppm})$, which is typical of the Bakal Deposit (Kuznetsov et al., 2005). The strontium content in siderite increases (samples $\mathrm{K}-1 / 5,39.41 \mathrm{ppm}$, and S-3, $15.05 \mathrm{ppm}$ ) in the contact zones and approaches that in dolomites. The measured ${ }^{87} \mathrm{Sr} /{ }^{86} \mathrm{Sr}$ ratio in siderite of the main ore phase is $0.7328-0.7385$, but in siderite of the VostochnoBulandikhinskii quarry, it decreases to $0.7177-0.7334$ (Table 3). The measured ${ }^{87} \mathrm{Sr} /{ }^{86} \mathrm{Sr}$ ratio in stromatolite dolomite is 0.7084 . This ratio in clayey limestone, dolomite, and siderite near shale rocks increases to $0.7153,0.7294-0.7419$, and 0.7442 , respectively (Table 3). Sedimentary limestone, with a minimum content of terrigenous admixture, were detected only on the eastern periphery of the ore field at Mt. Berezovaya in the Berezov Unit. They have the highest concentrations of strontium (up to $2000 \mathrm{ppm}$ ) and low ${ }^{87} \mathrm{Sr} /{ }^{86} \mathrm{Sr}$ values $(0.7046-0.7048)$, characteristic of the Early Riphean Ocean (Semikhatov et al., 2009; Kuznetsov et al., 2018).

The $\mathrm{Sm}$ and $\mathrm{Nd}$ concentrations in siderite vary from $0.13-0.96$ to $0.23-2.86 \mathrm{ppm}$, respectively; in dolomites, from $0.05-0.84$ to $0.20-4.84 \mathrm{ppm}$; and in clayey stromatolite limestone, from 0.36 to $2.02 \mathrm{ppm}$
(Table 3). The Sm and Nd concentrations in sedimentary limestone of the Bakal Formation are even lower (at the level of $0.06 \mathrm{ppm}$ ) and are not suitable for isotopic studies. The $\mathrm{Sm} / \mathrm{Nd}$ ratio in siderite is significantly higher $(0.30-0.66)$ than that in dolomite $(0.20-0.25)$ and limestone (0.18), which is explained by the high concentrations of samarium and closeness of its ionic radius to that of iron versus neodymium (mineralogical control). The $\mathrm{Sm}-\mathrm{Nd}$ characteristics of Riphean sedimentary limestone $\left({ }^{147} \mathrm{Sm} /{ }^{144} \mathrm{Nd}=\right.$ $\left.0.1297-0.1501,{ }^{143} \mathrm{Nd} /{ }^{144} \mathrm{Nd}=0.51157-0.51179\right)$ of the underlying Satka Formation (Krupenin et al., 2016) are close to those of limestone and dolomite of the Bakal Formation, but differs from siderite $\left({ }^{147} \mathrm{Sm} /{ }^{144} \mathrm{Nd}=0.1797-0.4016,{ }^{143} \mathrm{Nd} /{ }^{144} \mathrm{Nd}=\right.$ 0.51179-0.51322) (Table 3).

\section{DISCUSSION}

The Sm-Nd systematics of siderite of hydrothermal genesis has to date not been studied. The only one was performed with an example of siderite veins hosting the $\mathrm{Ag}$-polymetal mineralization of the Jebel Avam Deposit in Late Paleozoic shale-carbonate rocks of the Atlas Mountains (Castorina and Masi, 2008). In this deposit, the $\mathrm{Sm}$ and $\mathrm{Nd}$ concentrations in hydrothermal vein siderite are higher by an order of 


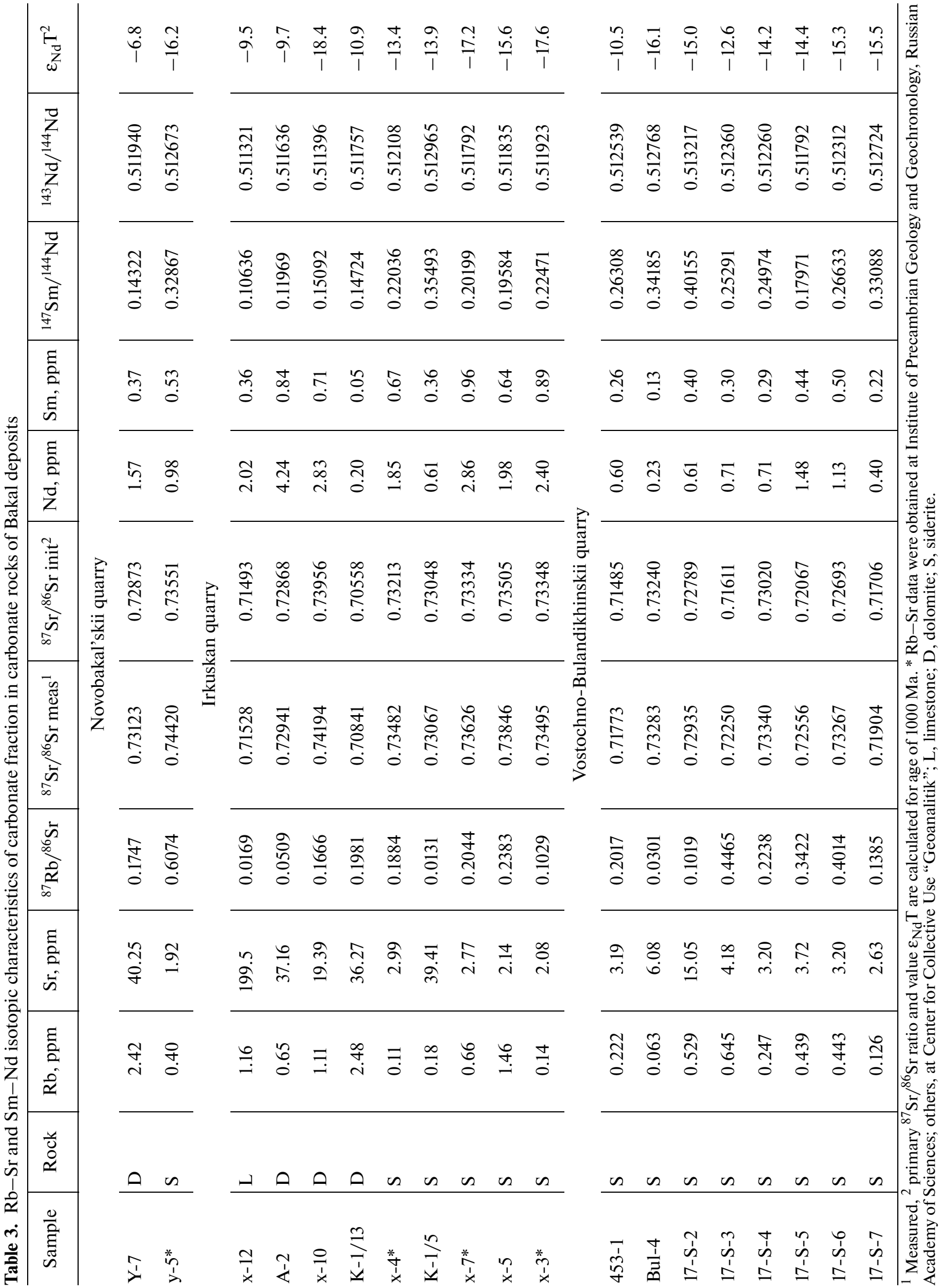




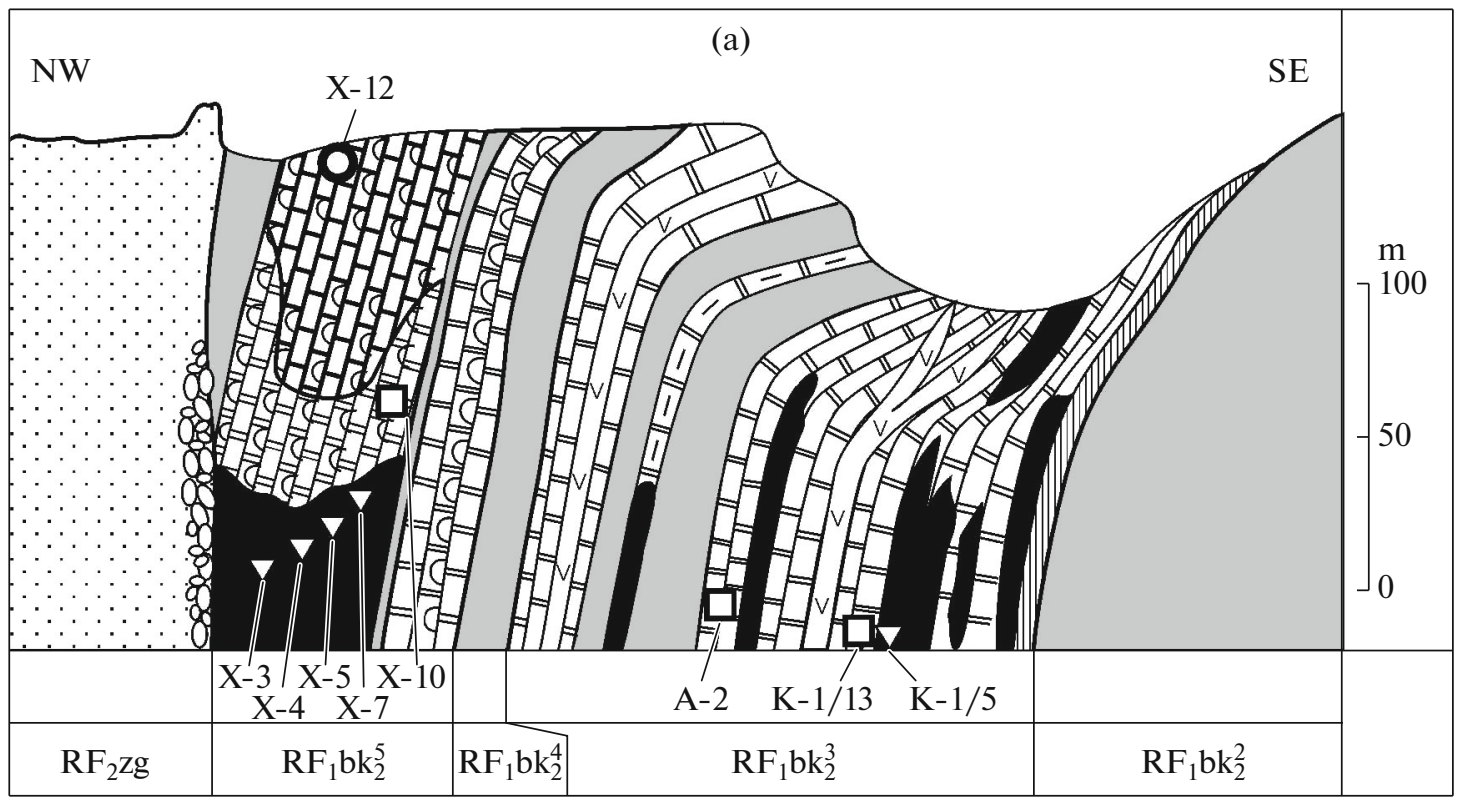

(b)
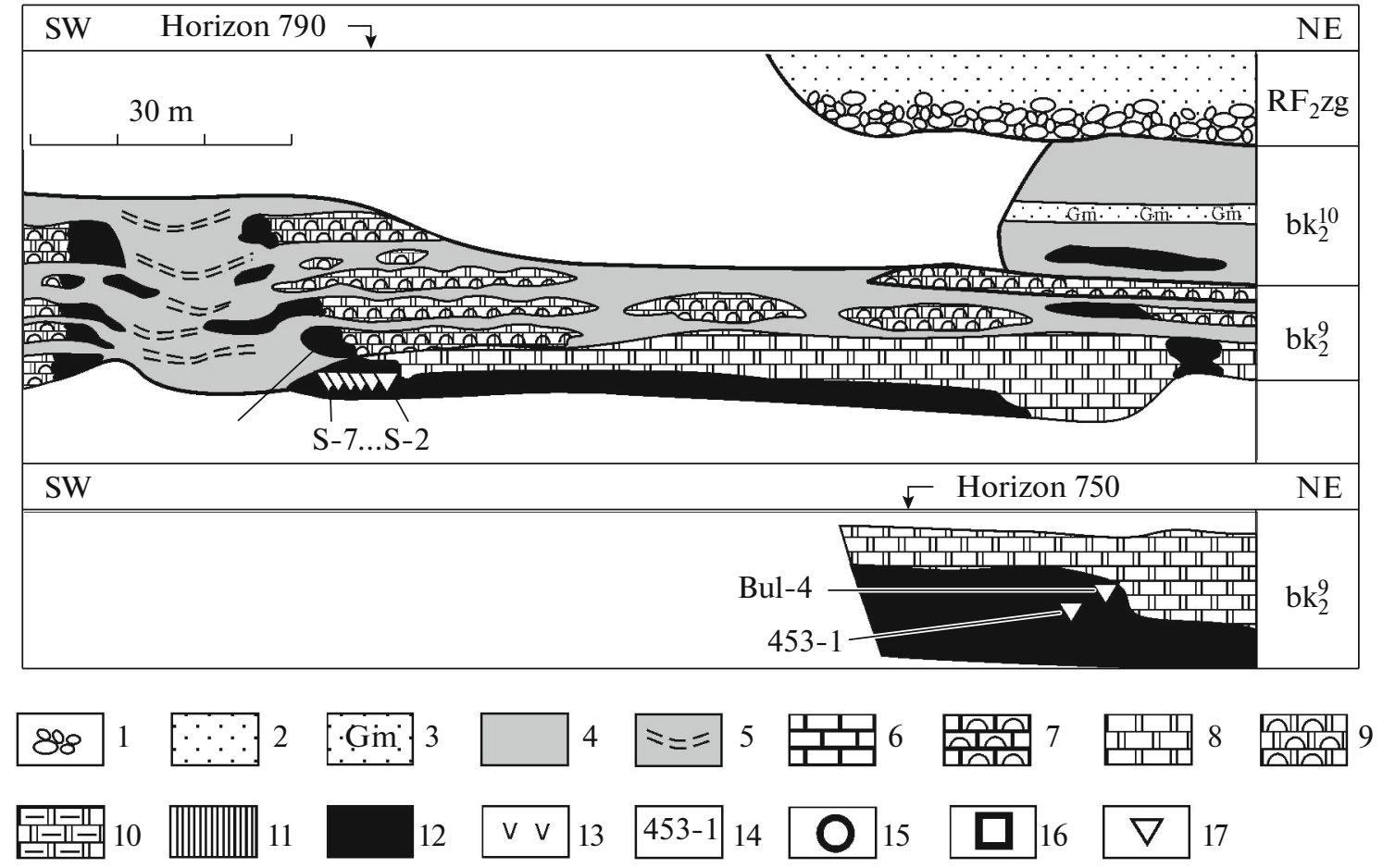

Fig. 4. Schematic geological profiles. (a) Northeastern wall of Tsentral'nyi quarry of Irkuskan Mine, (b) northwestern edge of Vostochno-Bulandikhinskii quarry (modified after Kuznetsov et al., 2005). (1-13) Rock types: (1) conglomerate, (2) sandstone, (3) sandstone with hematite, (4) low-carboniferous silty-argillaceous shale, (5) greenish gray shale in karst zone, (6) limestone, (7) stromatolite limestone, (8) dolomite, (9) stromatolite dolomite, (10) clayey dolomite, (11) magnesite, (12) siderite, (13) diabase dikes; (14) sample nos.; (15-17) samples: (15) limestone, (16) dolomite, (17) siderite. Abbreviations in figure: bk ${ }_{2}^{2}$, Irkuskan Unit, $\mathrm{bk}_{2}^{3}$, Shuida Unit, $\mathrm{bk}_{2}^{4}$, Nadshuida Unit, $\mathrm{bk}_{2}^{5}$, Gaev Unit, $\mathrm{bk}_{2}^{9}$, Verkhnebakal Unit, $\mathrm{bk}_{2}^{10}$, Bulandikha Unit, $\mathrm{RF}_{2} \mathrm{zg}$, Middle Riphean Zigal'ga Formation. 


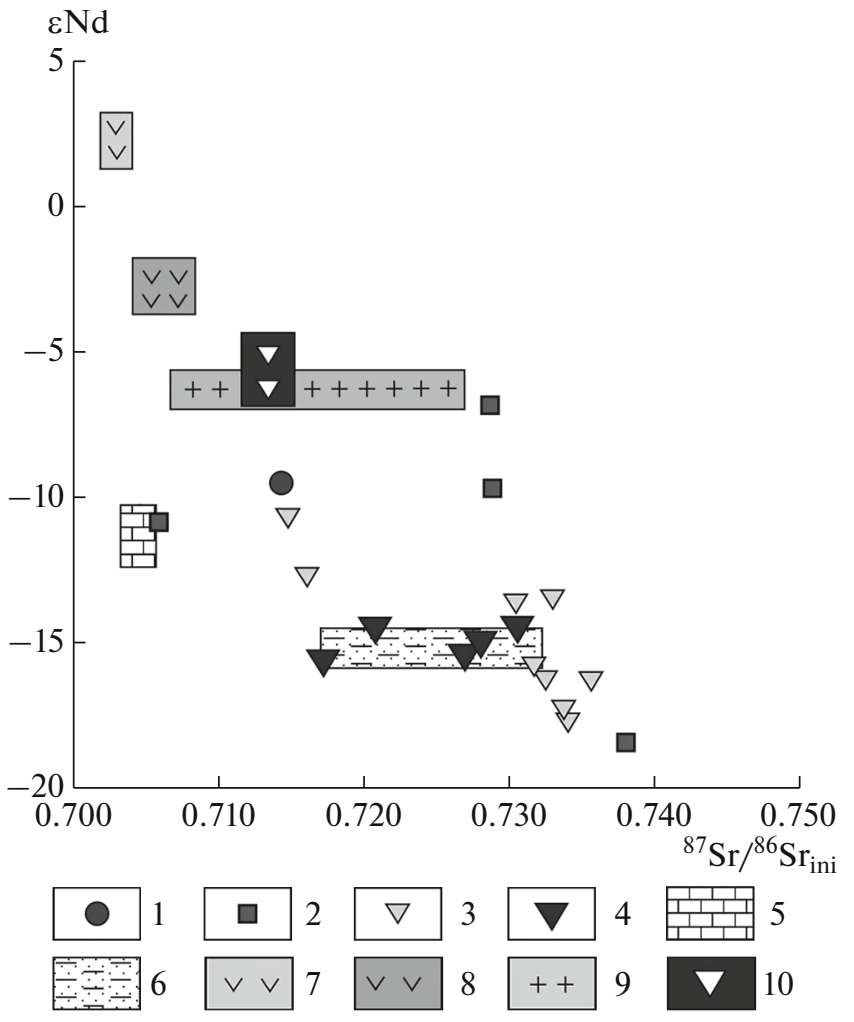

Fig. 5. Comparison of $\varepsilon_{\mathrm{Nd}}(\mathrm{T})$ and initial ${ }^{87} \mathrm{Sr} /{ }^{86} \mathrm{Sr}$ ratio in carbonate rocks of Bakal ore field with Riphean sedimentary limestone and shale. (1) Limestone; (2) dolomite; (3) siderite; (4) siderite from central part of orebody in Vostochno-Bulandikhinskii quarry; (5) Lower Riphean sedimentary limestone, Satka Formation, Southern Urals (Krupenin et al., 2016); (6) shale of Bakal Formation (Gorokhov et al., 1982; Maslov et al., 2003); (7) gabbro of Berdyaush Massif (Larin, 2011), (8) gabbro of KusinskoKopanskaya intrusion (Kholodnov et al., 2010); (9) rapakivi granite of Berdyaush Massif (Larin, 2011); (10) vein siderite of Atlas Mountains (Castorina and Masi, 2008).

magnitude vesus Bakal siderite. The $\varepsilon_{\mathrm{Nd}}(\mathrm{T})$ values in vein siderite were calculated for the probable age of the mineralization $(280 \mathrm{Ma}):-5.7 \pm 0.8$. These values turned out to be intermediate between the $\varepsilon_{\mathrm{Nd}}(\mathrm{T})$ values in the host shale ( -6 to -11$)$ and intruding granite $(-1.5$ to -3.0$)$. This allowed the authors to suggest the hydrothermal postmagmatic origin of the ore fluid, genetically related to collisional processes in Alpine folding. In this case, the $\mathrm{Nd}$ isotopic composition of the ore fluid formed with the participation of solutions from two sources: the host shale and intruding granite. This conclusion is additionally supported by data on the isotopic composition of strontium, carbon, and oxygen, and the presence of a sharp positive Eu anomaly in siderite (Castorina and Masi, 2008).

For all intents and purposes, we have studied the Sm-Nd systematics of hydrothermal-metasomatic siderite for the first time. Variations in the $\mathrm{Sm} / \mathrm{Nd}$ ratio recorded in siderite of the Bakal Deposit make it

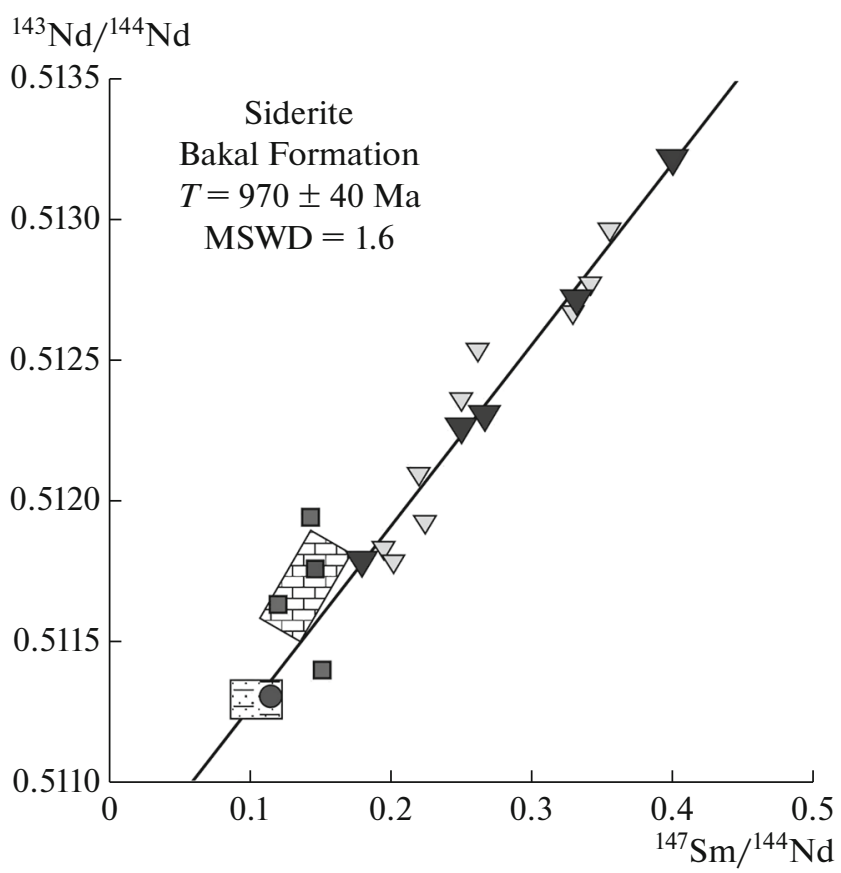

Fig. 6. $\mathrm{Sm}-\mathrm{Nd}$ isotopic data for carbonate rocks of Bakal ore field. Sm-Nd age was calculated for five samples of siderite without admixture of dolomite from central part of siderite body in Vostochno-Bulandikhinskii quarry.

possible to consider them a potential target for Sm$\mathrm{Nd}$ dating. The correlation for all siderite samples in coordinates ${ }^{147} \mathrm{Sm} /{ }^{144} \mathrm{Nd}-{ }^{143} \mathrm{Nd} /{ }^{144} \mathrm{Nd}$ yields a line with an age of $998 \pm 130 \mathrm{Ma}(\mathrm{MSWD}=19)$. The broad scattering of points is explained by inclusion in the calculation of samples from contact zones and subjected to postore processes. This age is $987 \pm 430 \mathrm{Ma}$ $(\mathrm{MSWD}=18)$ for siderite from the central parts of orebodies in the Irkuskan quarry. The minimum deviation is typical of sideroplesite samples from the profile in the orebody of the Vostochno-Bulandikhinskii quarry (samples S-2, ..., S-7; see Fig. 4b), which do not contain dolomite admixtures and plot in the $\mathrm{Sr}-$ $\mathrm{Nd}$ isotope field of the Bakal shale (Fig. 5). If we exclude sample S-3 from the set for calculating the age, which has a high strontium content $(15.05 \mathrm{ppm})$ associated with incomplete isotope-geochemical alterations in the metasomatic product, then we obtain a more accurate age of $970 \pm 40 \mathrm{Ma}, \mathrm{MSWD}=1.6$ (Fig. 6). These samples have the purest composition without dolomite admixtures or residual calcium and strontium concentrations of the limestone protolith. Complete rearrangement of the $\mathrm{Sm}-\mathrm{Nd}$ isotope system occurred in these samples, and their age most closely corresponds to the time of metasomatic recrystallization, previously estimated by the $\mathrm{Pb}-\mathrm{Pb}$ method as $1010 \pm 100 \mathrm{Ma}$ (Kuznetsov et al., 2005).

Thus, the two isotopic systematics yield close ages of metasomatic ferruginous carbonates for the Bakal deposits, which significantly verifies the age boundary 
of the formation of siderite mineralization, close to $1000 \mathrm{Ma}$.

Study of the age of metasomatic siderite using the $\mathrm{Sm}-\mathrm{Nd}$ systematics is not a routine method. We know of only one successful case of such application for estimating the age of metasomatic siderite of the Erzberg Deposit, the largest in Western Europe. This siderite deposit, with total reserves of up to $400 \mathrm{mln} \mathrm{t}$, is confined to the Paleozoic volcanosedimentary sequence, structurally located in the Greywacke Zone of the Eastern Alps (Styria, Austria), and has been mined for more than 1300 years (Redlich, 1916; Obruchev, 1935). Orebodies of coarse-crystalline siderite with complex shape, up to $200 \mathrm{~m}$ thick, metasomatically replace fine-grained Devonian limestone with the formation of a thin contact zone of ankerite and preservation of sedimentary structures in all varieties of carbonate rocks and ores. There is no wide zone of ferruginous dolomite around siderite deposits, like what we observe at the Bakal deposit. The age of siderite is $208 \pm 22 \mathrm{Ma}(\mathrm{MSWD}=4.6)$ and is confined to the divergent phase at the beginning of the Alpine tectogenesis cycle (Prochaska, 2016). Unfortunately, the author of the cited publication did not provide the initial $\mathrm{Sm}-\mathrm{Nd}$ isotopic data, except for a graph with the $\mathrm{Sm}-\mathrm{Nd}$ isochron.

The $\varepsilon_{\mathrm{Nd}}(\mathrm{T})$ value calculated for the Bakal ore field, taking into account the estimated age of siderite metasomatism (1000 Ma), varies from -13.4 to -17.6 in siderite of the central parts of ore units, and from -10.5 to -12.6 in siderite of the peripheral zones. The $\varepsilon_{\mathrm{Nd}}(\mathrm{T})$ value in most dolomites and limestone, is significantly higher, from -6.8 to -10.9 , and in one dolomite near a clay member, it decreases sharply to -18.4 (Fig. 5). The $\varepsilon_{\mathrm{Nd}}(1430)$ values for host shale of the Bakal Formation are -8 (Maslov et al., 2003). The $\varepsilon_{\mathrm{Nd}}(\mathrm{T})$ value for shale of the Bakal Formation recalculated for an age of $1000 \mathrm{Ma}$, is -13.6 , which is very close to the corresponding $\varepsilon_{\mathrm{Nd}}(1000)$ value for siderite. The low $\varepsilon_{\mathrm{Nd}}$ values are typical of rocks formed upon alteration or assimilation of older crustal formations with a $\mathrm{Sm} / \mathrm{Nd}$ ratio lower than in the original chondrite reservoir (Fore, 1989). It is highly probable that the neodymium isotopic composition of orebearing fluids was formed as a result of intense interaction of buried solutions with shale of the Riphean sedimentary basin. The data of the $\mathrm{Sm}-\mathrm{Nd}$ systematic reflect the crustal nature of the iron-bearing fluid from which the Bakal siderite formed.

The position of siderite on the ${ }^{87} \mathrm{Sr} /{ }^{86} \mathrm{Sr}_{\text {orig. }}-\varepsilon_{\mathrm{Nd}}(\mathrm{T})$ plot differs significantly from the field of rift gabbrogranite intrusions of the Middle Riphean occurring in the area of the Bakal deposits (Fig. 5). Even in comparison with the host Riphean marine limestone (0.7046-0.7048 and -10.7 to -12.3$)$, siderite is significantly enriched in crustal $\mathrm{Sr}$ and $\mathrm{Nd}$. At the same time, siderite plots in the field of shale of the Bakal Formation $(\varepsilon \mathrm{Nd}(\mathrm{T})$ values are recalculated for $1000 \mathrm{Ma})$.
This is consistent with the geochemical model of the formation of iron ore fluid due to the interaction of catagenetic solutions with silty-shale rocks in the Riphean sedimentary basin (Anfimov, 1997; Krupenin, 1999, 2017; Kuznetsov et al., 2005).

The idea of a geological model for the formation of such large accumulation of sideroplesite in carbonate rocks of the Bakal Formation is due to a favorable combination of a number of factors: lithogenetic, geotectonic, and structural.

Lithogenetic factor. The buried brines were the basis for the formation of high-Mg fluids, which contributed to both dolomitization of limestone and the formation of metasomatic magnesite deposits under the specific rift conditions of heating of carbonate layers upon migration in catagenesis (Krupenin and Kol'tsov, 2017). Magnesium is exchanged for iron in the process of interaction of aggressive chloride brines with shale under the thermodynamic conditions of deep catagenesis (Ellis, 1968; Drever, 1971; Maynard, 1985). Long-term interaction of brines with terrigenous-shale rocks in a catagenetic basin leads to a change in their composition to the ferruginous-magnesian. As a result, the formation of metasomatic Femagnesites and breinerites is probable (Krupenin and Kol'tsov, 2017; Krupenin et al., 2019).

Based on the data of (Yardley and Bodnar, 2014, Fig. 2.11), the metal/chloride ratio changes by five orders of magnitude between the low- and high-temperature hydrotherms $\left(60-400^{\circ} \mathrm{C}\right)$. In other words, the amount of $\mathrm{Fe}^{2+}$ mobilized by brines under the reducing conditions of the interiors increases sharply with increasing temperature of the brine fluid. This is important in the case of the formation of brines in the deep horizons of the super-rift depression. The magnesian-ferruginous chloride brine is formed in the high-temperature deep part of the rock basin. The tectonic activation stimulates its migration and discharge into the colder side parts of the former rift. Iron precipitates under the conditions of a decrease in solubility, when a brine fluid is introduced into carbonate rocks, and thus a mode of maximum favoring of $\mathrm{Fe}-$ metasomatism with the formation of sideroplesite is provided.

The chemical composition of fluid inclusions in Bakal siderite, corresponding to strong evaporite brines, was confirmed by special studies using the method of ion chromatography (Bottrell et al., 1988), by the high concentrations of chlorine and sodium, as well as bromine, which accumulates in solution under the conditions of evaporite thickening of seawater only (Prochaska and Krupenin, 2013). With the further evolution of the brine composition, the bromine concentrations are retained, being a stable tracer of the genetic nature of fluids (McCaffrey et al., 1987; Kesler et al., 1996; Leach et al., 2010). Such brines have a high potential for the leaching of metals (in particular iron) from shale upon migration, (Savard et al., 1998; 
Chaudhuri and Clauer, 1993; Kharaka and Thordsen, 1992). The interaction of fluids with sandy shale rocks leads to an increase in the proportion of radiogenic strontium and REE in solutions (Gorokhov et al., 1982, 2007, 2019). Epigenetic dolomite in the Riphean section of the Southern Urals usually has a higher ${ }^{87} \mathrm{Sr} /{ }^{86} \mathrm{Sr}$ ratio than that in the host limestone (Kuznetsov et al., 2008; Semikhatov et al., 2009; Kuznetsov et al., 2017). This ratio in metasomatic magnesite, ferruginous magnesite, and siderite becomes even higher (Frimell, 1988; Cortecci and Frizzo, 1993; Kuznetsov et al., 2007; Krupenin and Kuznetsov, 2009). For example, sedimentary limestone containing dolomite and magnesite of the Satka deposits has an average ${ }^{87} \mathrm{Sr} /{ }^{86} \mathrm{Sr}$ ratio of 0.7046 , 0.7076 , and 0.7137 , respectively. Similar characteristics for the host limestone, dolomite, and ferruginous magnesite of the Ismakaevskoe deposit are 0.7057, 0.7163, and 0.7180 (Krupenin and Kuznetsov, 2009). The ${ }^{87} \mathrm{Sr} /{ }^{86} \mathrm{Sr}$ ratio in the Bakal dolomite and siderite reaches even higher values, on the average, 0.7277 and 0.7336 , respectively (Table 3 ).

According to a number of researchers, the evolution of magnesian brines into $\mathrm{Mg}-\mathrm{Fe}$-bearing fluids was the reason for the formation of ferruginous carbonates after magnesian ones at deposits in the Paleozoic terrigenous-carbonate rocks of Central Europe (Frimmel, 1988; Radvanec et al., 2004; Prochaska, 2016). The geochemical evidence presented by Prochaska (2016) unequivocally indicates the origin of the ore solutions of the Erzberg siderite deposit from the brines of the Triassic evaporite basins submerged in the Paleozoic strata at the stage of rift extension. Hydrothermal iron ore fluids were formed during the interaction of aggressive brines with volcanogenicterrigenous host rocks under the redox conditions of catagenesis or low-temperature metamorphism (Prochaska, 2016).

The similar conditions probably occurred during the formation of $\mathrm{Fe}-\mathrm{Mg}$ metasomatic carbonates in the Riphean rocks of the Southern Urals. Using the example of the same Bakal ore field, we see that lowiron magnesite in the Shuydinskaya Unit of the Bakal Formation was controlled by the Mashak riftogenesis at the beginning of the Middle Riphean, while siderites were formed much later, in the Late Riphean (Krupenin, 1999; Ovchinnikova et al. , 2018). Another example is the ferruginous magnesite Ismakaevskoe Deposit (up to $5 \% \mathrm{FeO}$ ), which has a total thickness of up to $400 \mathrm{~m}$ in the Early Riphean deposits. However, according to the $\mathrm{Sm}-\mathrm{Nd}$ data, the formation of magnesite occurred at the end of the Middle Riphean, $\sim 1250 \mathrm{Ma}$ (Krupenin et al. , 2016). In addition, a breinerite body (up to $20.5 \% \mathrm{FeO}$ ) was found in the same limestone unit, $10 \mathrm{~km}$ to the south from Ismakaevo (Krupenin et al., 2019).

The geotectonic factor in the formation of siderite mineralization is controlled by the position of the ore field in the super-rift depression, namely, on the western flank of the Mashak rift, where iron-bearing solutions could be discharged from deeply submerged areas of the rift basin (super-rift depression) at the Grenville stage of tectonothermal activation. The age of $1000 \mathrm{Ma}$ is borderline for the geological evolution of the eastern margin of the Baltic. At this time, inversion and a change in the tectonic regime occurred. The evolution of the intracratonic sedimentary basin (superrift depression) after this boundary gave way to the formation of a large pericratonic basin, which occupied a wide area in the north and east (in modern coordinates) of Baltica (Maslov, 1997). There was a long hiatus in sedimentation more than $250 \mathrm{Ma}$ ago in the sedimentary sequence between the Middle Riphean Avzyan Formation and the Late Riphean Zil'merdak Formation (Maslov et al., 2018; Kuznetsov et al., 2017).

The deposits of the Bakal Formation subsided under the Middle Riphean deposits to depths of no more than $2.5-3 \mathrm{~km}$ by the time of the ore formation. Accordingly, the host rocks were heated to $120-150^{\circ} \mathrm{C}$ under the influence of the geothermal gradient. At the same time, the distribution of REE in ores and siderite-ankerite thermometry yield of ore deposition temperatures of $250-260^{\circ} \mathrm{C}$ in the central parts of the ore field and $180-220^{\circ} \mathrm{C}$ in the peripheral zones (Krupenin, 2017). The relatively high temperatures of the hydrothermal process indicate that the Bakal ore field became an discharge area of intraformational fluids coming from deeper and, accordingly, more heated parts of the paleohydrogeological basin at the Middle-Late Riphean boundary. The fluid formation zone was located in Lower Riphean sediments, presumably east of the ore field in the Mashak rift zone, where the thickness of the overlying Middle Riphean sediments sharply increased during active volcanosedimentary accumulation (Mashak Formation), and reaching $6-7 \mathrm{~km}$.

Studies of the oil-and-gas-bearing basins show that the discharge of catagenetic fluids occurs at the stages of tectonic activation, when gas-water solutions accumulated within thick shale units, which originated upon the formation of hydromica after smectites and caused abnormally high reservoir pressures, which penetrated into the upper horizons of the sedimentary crust. These solutions, mixed with infiltration waters, release gases and metals dissolved in them at the stage of temperature and pressure drop (Lebedev, 1992). We suggest that the relaxation of hydrothermal $\mathrm{Mg}-\mathrm{Fe}-$ rich fluids occurred at the regressive stage of the evolution of the Middle Riphean sedimentary basin. At that time, a series of faults formed under the influence of upward movements at the end of the Avzyan (the pre-Zilmerdak sedimentation hiatus), which facilitated the migration of elision fluids from the deep parts of the basin to low pressure zones on its periphery. 
The structural factor controls the conditions for the formation of deposits with unique reserves of siderite ores. This became possible due to the focusing of the fluid flow in the zone of the tectonic block, uplifted, inclined, and partially eroded in the pre-Zigal'ga (the initial period of formation of the Mashak graben), consisting of rocks of the Bakal Formation. Ascending solutions were preserved beneath the overlying quartzite sandstone of the Zigal'ga Formation, which were already significantly compacted and had negligible permeability by the end of the Middle Riphean (Krupenin, 1999); they were also relatively resistant to brittle deformations. Hydrothermal iron-magnesian chloride solutions with low $\mathrm{pH}$ produced metasomatic replacement in carbonate rocks of the Bakal Formation in the adjacent zone along a relatively permeable interformational unconformity surface and formed siderite-ankerite-dolomite zoning.

The formation of the world's largest accumulation of hydrothermal-metasomatic siderite ores at the 1000 Ma boundary in Riphean deposits of the Southern Urals was a major event in the formation sequence of other deposits of this time interval, which fell on the Middle-Late Riphean boundary. Most of the deposits are confined to the western side of the Mashak graben and are localized in the deposits of the Early and Middle Riphean. Two stages of mineragenic activity at this time may be distinguished: $1250-1200$ and $1000 \mathrm{Ma}$.

The first stage is associated with the formation of barite-polymetallic deposits and manifestations of the SEDEX-type in the deposits of the Avzyan Formation, which completes the section of the Middle Riphean, fluorites, and ferruginous magnesites. The $\mathrm{Sm}-\mathrm{Nd}$ age of $\mathrm{Fe}-\mathrm{magnesite}$ of the Ismakaevskoe Deposit in the Early Riphean rocks is $1250 \pm 130 \mathrm{Ma}$, despite too huge error due to the incomplete cogeneticity of magnesite samples, clearly tends to the same stage (Krupenin et al., 2016). In addition, vein and hydrothermal-metasomatic fluorites of the Suranskoe Deposit with an age of $1230 \mathrm{Ma}(\mathrm{Sm}-\mathrm{Nd}$ and $\mathrm{Rb}-\mathrm{Sr}$ methods) are confined to the same Early Riphean carbonate rocks in this area (Krupenin et al, 2012). A detailed study of the formation sequence of fluorite generations and their geochemical patterns indicates that fluorine was extracted from felsic igneous rocks of the Mashak graben upon interaction with catagenetic brines. This is supported by the brine nature of fluid inclusions, as well as by the high REE concentrations and negative Eu anomaly in the major fluorite generations. The barite-polymetallic mineralization forming stratified sulfide ores is widespread in the Avzyan Formation of the Middle Riphean (Kuzhinskoe and Verkhne-Arshinskoe deposits and a number of ore occurrences). The sulfur isotopic composition of sulfides suggests primary sedimentary ore accumulation due to the cyclic sulfate reduction upon discharge of metalliferous thermal exhalations in the seafloor depressions $\left(\delta^{34} \mathrm{~S}\right.$ is $+21-26 \%$ ) (Krupenin, 2004).
The second stage ( $\sim 1000 \mathrm{Ma})$ includes the formation of siderite of the Bakal ore field. Most likely, the deposits of metasomatic ankerite were formed in the Avzyan Formation at the same stage.

It is important to note that, despite the extensive development of thick carbonate and terrigenous units (which can be both reservoirs and a source of catagenic fluids), not a single magnesite and siderite deposit is observed in the overlying deposits of the Upper Riphean. This emphasizes the importance of the Middle-Late Riphean boundary for the formation of the minerogenic character of the region.

\section{CONCLUSIONS}

(1) The first study of the $\mathrm{Sr}-\mathrm{Nd}$ isotope systematics of hydrothermal-metasomatic siderite was carried out based on the example of the Bakal deposits, the world's largest accumulation of this type of iron ore.

(2) The source of the hydrothermal fluid from which the metasomatic siderite of the Bakal deposits formed is supported by data on the isotopic composition of strontium, indicating interaction of iron-bearing fluids with terrigenous-shale rocks of the Riphean sedimentary basin, as well as by data of the Nd-systematics, indicating the crustal nature of the fluid.

(3) The formation model for Precambrian siderite at the Grenville stage of tectonothermal activation, rather than during the Mashak rifting event at the beginning of the Middle Riphean, has been supported for the first time by $\mathrm{Sm}-\mathrm{Nd}$ isotopic data and refines the first estimate of the age of mineralization by the $\mathrm{Pb}-\mathrm{Pb}$ method. Application of two isotopic systems for the direct study of the age of siderite significantly verifies the age of the siderite mineralization of the Bakal group of deposits.

(4) The identified age limit of $\sim 1000 \mathrm{Ma}$ is associated with tectonic restructuring in the region (the eastern margin of Baltica) at the Middle-Upper Riphean boundary, which was of decisive importance for the formation of a number of stratiform and hydrothermal-metasomatic deposits in the Southern Urals. It was at this time that the minerogenic character of the region was formed; further tectonic restructurings only complicated the orebodies.

\section{ACKNOWLEDGMENTS}

The authors are grateful to the Geoanalitik Collective Use Center, Institute of Geology and Geochemistry, Ural Branch, Russian Academy of Sciences, for analyses.

\section{FUNDING}

The research was supported under the state task of the Institute of Geology and Geochemistry, Ural Branch, Russian Academy of Sciences (topic no. 0393-2016-0022 "Geobiospheric Processes and Their Reflection in the Iso- 
topic-Geochemical Characteristics of Sedimentary and Volcanosedimentary Formations," and was partly by topic no. FMUW-2021-0003).

\section{CONFLICT OF INTEREST}

The authors declare that they have no conflict of interest.

\section{OPEN ACCESS}

This article is licensed under a Creative Commons Attribution 4.0 International License, which permits use, sharing, adaptation, distribution and reproduction in any medium or format, as long as you give appropriate credit to the original author(s) and the source, provide a link to the Creative Commons license, and indicate if changes were made. The images or other third party material in this article are included in the article's Creative Commons license, unless indicated otherwise in a credit line to the material. If material is not included in the article's Creative Commons license and your intended use is not permitted by statutory regulation or exceeds the permitted use, you will need to obtain permission directly from the copyright holder. To view a copy of this license, visit http://creativecommons.org/licenses/by/4.0/.

\section{REFERENCES}

Anfimov, L.V., Litogenez $v$ rifeiskikh osadochnykh tolshchakh Bashkirskogo megantiklinoriya (Yu. Ural) (Lithogenesis in Riphean Sedimentary Sequences of the Bashkir Meganticlinorium, South Urals), Ykaterinburg: UrO RAN, 1997.

Anfimov, L.V., Busygin, B.D., and Krupenin, M.T., Iron distribution in rocks of the Riphean Bakal siderite formation (South Urals), Litol. Polezn. Iskop., 1984, no. 4, pp. 136-143.

Annovitz, L.M. and Essene, E.J., Phase equilibria in the system $\mathrm{CaCO}_{3}-\mathrm{MgCO}_{3}-\mathrm{FeCO}_{3}$, J. Petrol., 1987, vol. 28, no. 2, pp. 389-414.

Borshchevskii, Yu.A., Borisova, S.L., Lazur, O.G., et al., Carbon and oxygen isotope composition of the Bakal and Satka deposits, Karbonatnoe osadkonakoplenie i problema evaporitov $v$ dokembrii (Carbonate Sedimentation and Problem of Evaporites in the Precambrian), Rostov-on-Don: Rost. Univ., 1978, pp. 98-100.

Bottrell, S.H., Yardley, B.W.D., and Buckley, F., A modified crush-leach method for the analysis of fluid inclusion electrolytes, Bull Mineral, 1988, vol. 111, pp. 279-290.

Castorina, F. and Masi, U., REE- and Nd-isotope evidence for the origin of siderite from the Jebel Awam deposit (Central Morocco), Ore Geol. Rev., 2008, vol. 24, pp. 337-342.

Chaudhuri, S. and Clauer, N., Strontium isotopic compositions and potassium and rubidium contents of formation waters in sedimentary basins: clues to the origin of the solutes, Geochim. Cosmochim. Acta, 1993, vol. 57, no. 3, pp. 429-437.

Cortecci, G. and Frizzo, P., Origin of siderite deposits from the Lombardy valleys, nothern Italy: a carbon, oxygen and strontium isotope study, Chem. Geol. (Isot. Geosci. Section), 1993, vol. 105, no. 4, pp. 293-303.
Davydenko, Yu.A., Uglovye stratigraficheskie nesoglasiya kak faktor lokalizatsii endogennogo orudeneniya (Angular Stratigraphic Unconformities as Ore-Controlling Factor), Tr. Irkut. Gorno-metallurg. Inst. Blagoveshchensk, Ser. Geol., 1956, vol. 10, pp. 33-39.

Drever, J.I., Magnesian-iron replacement in clay minerals in anoxic marine sediments, Science, 1971, vol. 172, no. 3990, pp. 1334-1336.

Druzhinin, I.P., Cyclical structure of the Bakal iron-bearing sediments, South Urals, Dokl. Akad. Nauk SSSR, 1971, vol. 196, no. 6, pp. 1410-1413.

Dunaev, V.A., Distribution of siderites in the Bakal district, South Urals, Litol. Polezn. Iskop., 1983, no. 4, pp. 129-133.

Ellis, A.J., Natural hydrothermal systems and experimental hot water/rock interaction: reaction with $\mathrm{NaCl}$ solutions and trace metal extraction, Geochim. Cosmochim. Acta, 1968, vol. 32, pp. 1356-1363.

Ellmies, R., Voightlaunder, G., Germann, K., Krupenin, M.T., and Moeller, P., Origin of giant stratabound deposits of magnesite and siderite in Riphean carbonate rocks of the Bashkir mega-anticline, Western Urals, Geol. Rundsch., 1999, pp. 589-602.

Ernst, R.E., Pease, V., Puchkov, V.N., Kozlov, V.I., Sergeeva, N.D., and Hamilton, M., Geochemical characterization of Precambrian magmatic suites of the southeastern margin of the East European craton, Southern Urals, Russia, Geol. Sbornik, 2006, no. 5, pp. 119-161.

Frimmel, H., Strontium isotopic evidence for the origin of siderite, ankerite and magnesite mineralizations in the Eastern Alps, Mineral. Deposita, 1988, vol. 23, no. 2, pp. 268-275.

Gorokhov, I.M., Mel'nikov, N.N., Kuznetsov, A.B., Konstantinova, G.V., and Turchenko, T.L., Sm-Nd systematics of fine-grained fractions of the Lower Cambrian blue clay in Northern Estonia, Lithol. Miner. Resour., 2007, no. 5, pp. 482-496.

Gorokhov, I.M., Varshavskaya, E.S., Kutyavin, E.P., and Mel'nikov, N.N., Influence of low metamorphism on the $\mathrm{Rb}-\mathrm{Sr}$ systems in sedimentary and volcanogenic rocks, Litol. Polezn. Iskop., 1982, no. 5, pp. 81-90.

Gorokhov, I.M., Zaitseva, T.S., Kuznetsov, A.B., Ovchinnikova, G.V., Arakelyants, M.M., Kovach, V.P., Konstantinova, G.V., Turchenko, T.L., and Vasil'eva, I.M., Isotope systematics and age of authigenic minerals in shales of the Upper Riphean Inzer Formation, South Urals, Stratigraphy. Geol. Correlation, 2019, vol. 27, no. 2, pp. 133-158.

Grazhdankin, D.V., Marusin, V.V., Meert, J., Krupenin, M.T., and Maslov, A.V., Kotlin regional stage in the South Urals, Dokl. Earth Sci., 2011, vol. 440, no. 1, pp. 122-1226.

Kesler, S.E., Martini, A.M., Appold, M.S., Walter, L.M., Huston, T.J., and Furman, F.C., $\mathrm{Na}-\mathrm{Cl}-\mathrm{Br}-$ systematics of fluid inclusions from Mississippi Valley-Type deposits, Appalachian basin: constraints on solute origin and migration paths, Geochim. Cosmochim. Acta, 1996, vol. 60, pp. 225-233.

Kharaka, Y.K. and Thordsen, J.J., Stable isotope geochemistry and origin of waters in sedimentary basins, In Isotopic Signatures and Sedimentary Records - Lecture Notes in Earth Sciences, Chaudhuri, S. and Clauer, N., Eds., (SpringerVerlag, Berlin, 1992), pp. 411-466.

Kholodnov, V.V., Fershtater, G.B., Ronkin, Yu.L., Borodina, N.S., Pribavkin, S.V., and Lepikhina, O.P., Sm-Nd 
and $\mathrm{Rb}-\mathrm{Sr}$ ages of gabbroids, granitoids, and titanomagnetite ores from layered intrusions of the Kusa-Kopan Complex (South Urals), Dokl. Earth Sci. 2010, vol. 432, no. 5, pp. 732-736.

Kholodov, V.N. and Butuzova, G.Yu., Siderite formation and evolution of sedimentary iron ore deposition in the Earth's history, Geol. Ore Deposits, 2008, vol. 50, no. 4, pp. 299-319.

Krasnobaev, A.A., Kozlov, V.I., Puchkov, V.N., Busharina, S.V., Sergeeva, N.D., and Paderin, I.P., Zircon geochronology of the Mashak volcanic rocks and the problem of the age of the Lower-Middle Riphean boundary (Southern Urals), Stratigraphy. Geol. Correlation, 2013, vol. 21, no. 5, pp. 465481.

Krupenin, M.T., The Middle Riphean time on the western slope of the Southern Urals: mineragenic and geodynamic implications, Dokl. Earth Sci., 2004, vol. 399A, no. 9, pp. 1189-1191.

Krupenin, M.T., Temperature of organic metasomatism of the Bakal siderite deposit: geochemical data, Vestn. Permsk. Univ., Geol., 2017, vol. 16, no. 2, pp. 167-178.

Krupenin, M.T., Usloviya formirovaniya sideritonosnoi bakal'skoi svity nizhnego rifeya (Yuzhnyi Ural) (Conditions of Formation of the Lower Riphean Siderite-Bearing Bakal Formation, the South Urals), Yekaterinburg: UrO RAN, 1999.

Krupenin, M.T. and Kol'tsov, A.B., Geology, composition, and physicochemical model of Sparry magnesite deposits of the Southern Urals, Geol. Ore Deposits, 2017, vol. 59, no. 1, pp. 14-35.

Krupenin, M.T. and Kuznetsov, A.B., Sr-isotope characteristics of magnesites and host carbonate rocks, Lower Riphean, South Uralian Province, Litosfera, 2009, no. 5, pp. 56-71.

Krupenin, M.T., Kuznetsov, A.B., and Konstantinova, G.V., Comparative $\mathrm{Sr}-\mathrm{Nd}$ systematics and REE distribution in typical Lower Riphean magnesite deposits sof the South Uralian Province, Litosfera, 2016, no. 5, pp. 58-80.

Krupenin, M.T., Michurin, S.V., Sharipova, A.A., Garaeva, A.A., Zamyatin, D.A., and Gulyaeva, T.Ya., Formation conditions of ferromagnesian metasomatic carbonates in the Lower Riphean terrigenous-carbonate rocks of the Southern Urals, Lithol. Miner. Resour., 2019, vol. 54, no. 3, pp. 248-261.

Krupenin, M.T., Prokhaska, V., and Ronkin, Yu.L., Staged formation of the fluorites of the Suran deposit (Bashkir meganticlinorium): evidence from REE data, fluid inclusions, and $\mathrm{Sr}-\mathrm{Nd}$ systematics, Litosfera, 2012, no. 5. C. 126-144.

Kuznetsov A.B., Krupenin M.T., Gorokhov I.M., Maslov A.V., Konstantinova G.V., Strontium isotopic composition of Lower Riphean carbonate rocks in the magnesite-bearing Satka Formation, Southern Urals, Dokl. Earth Sci., 2007, vol. 414, no. 2, pp. 599-604.

Kuznetsov, A.B., Krupenin, M.T., Ovchinnikova, G.V., Gorokhov, I.M., Maslov, A.V. Kaurova, O.K., and Ellmies, R., Diagenesis of carbonate and siderite deposits of the Lower Riphean Bakal Formation, the Southern Urals: Sr isotopic characteristics and $\mathrm{Pb}-\mathrm{Pb}$ age, Lithol. Miner. Resour., 2005, vol. 40, no. 3, pp. 195-215.

Kuznetsov, A.B., Ovchinnikova, G.V., Gorokhov, I.M., Kaurova, O.K., Krupenin, M.T., and Maslov, A.V., Sr-isotope signature and $\mathrm{Pb}-\mathrm{Pb}$ age of the Bakal Formation lime- stones in the Lower Riphean type section, the Southern Urals, Dokl. Earth Sci., 2003, vol. 391A, no. 6, pp. 819-822.

Kuznetsov A.B., Ovchinnikova G.V., Semikhatov M.A., Gorokhov I.M., Kaurova O.K., Krupenin, M.T., Vasil'eva, I.M., Gorokhovskii, B.M., and Maslov, A.V., The $\mathrm{Sr}$ isotopic characterization and $\mathrm{Pb}-\mathrm{Pb}$ age of carbonate rocks from the Satka Formation, the Lower Riphean Burzyan Group of the Southern Urals, Stratigraphy. Geol. Correlation, 2008, vol. 16, no. 2, pp. 120-137.

Kuznetsov, A.B., Semikhatov, M.A., and Gorokhov, I.M., Strontium isotope stratigraphy: principles and state of the art, Stratigraphy. Geol. Correlation, 2018, vol. 26, no. 4, pp. 367-386.

Kuznetsov, A.B., Bekker, A., Ovchinnikova, G.V., Gorokhov, I.M., and Vasilyeva, I.M., Unradiogenic strontium and moderate-amplitude carbon isotope variations in Early Tonian seawater after the assembly of Rodinia and before the bitter springs excursion, Precambrian Res., 2017, vol. 298, pp. 157-173.

Larin, A.M., Granity rapakivi $i$ assotsiiruyushchie porody (Rapakivi Granites and Associated Rocks), St. Petersburg: Nauka, 2011.

Leach, D., Taylor, R.D., Fey, D.L., Diehl, S.F., and Saltus, R.W., Deposit model for Mississippi valley-type leadzinc ores, Sci. Investig. Rep., 5070-A, (2010).

Lebedev, B.A., Geokhimiya epigeneticheskikh protsessov v osadochnykh basseinakh (Geochemistry of Epigenetic Processes in Sedimentary Basins), Leningrad: Nedra, 1992.

Malakhov, A.E., Main geological questions of Bakal, Voprosy razvitiya Bakal'skoi rudnoi bazy (Problems of Evolution of the Bakal Ore Base), Sverdlovsk: UFAN SSSR, 1957, pp. 93-112.

Martynov, K.V., Experimental study of $\mathrm{Mg}$ and Fe partitioning between ankerite and breynerite in the $\mathrm{MgCO}_{3}-\mathrm{Ca}-$ $\mathrm{CO}_{3}-\mathrm{FeCO}_{3}$ system at $250-450^{\circ} \mathrm{S}$ and thermodynamic properties of ankerite, Geokhimiya, 1990, no. 12, pp. 16881695.

Maslov, A.V., Osadochnye assotsiatsii rifeya stratotipicheskoi mestnosti (evolyutsiya vzglyadov na usloviya formirovaniya, litofatsial'naya zonal'nost') (Sedimentary Associations of the Riphean Stratotype Area: Evolution of Points of View on the Conditions of Formation, Lithofacies Zoning), Yekaterinburg: UrO RAN, 1997. $220 \mathrm{~s}$.

Maslov, A.V., Erokhin, E.V., Gerdes, A., Ronkin, Yu.L., and Ivanov, K.S., First results of $\mathrm{U}-\mathrm{Pb} \mathrm{LA}-\mathrm{ICP}-\mathrm{MS}$ isotope dating of detrital zircons from arkose sandstone of the Biryan Subformation of Zilmerdak Formation (Upper Riphean, South Urals), Dokl. Earth Sci., 2018, vol. 482, no. 2, pp. 1275-1277.

Maslov, A.V., Krupenin, M.T., Gareev, E.Z., and Anfimov, L.V., Rifei zapadnogo sklona Yuzhnogo Urala (klassicheskie razrezy, sedimento- $i$ litogenez, minerageniya, geologicheskie pamyatniki prirody), (Riphean of the Western Slope of the South Urals (Classical Sections, Sedimento- and Lithogenesis, Metallogeny, and Geological Monuments), Yekaterinburg: UrO RAN, 2001, vol. 1.

Maslov, A.V., Ronkin, Yu.L., Krupenin, M.T., Gareev, E.Z., and Lepikhina, O.P., Provenances of Riphean sedimentary basins at the Russian Platform-Southern Urals junction: evidence from petrographic, petrochemical, and geochemical data, Dokl. Earth Sci. 2003, vol. 389, no. 2, pp. 180183. 
McCaffrey, M.A., Lazar, B., and Holland, H.D., The evaporation path of seawater and the coprecipitation of $\mathrm{Br}-$ and K+ with halite, J. Sediment. Petrol., 1987, vol. 57, no. 5, pp. 928-937.

Maynard, J.B. Geochemistry of Sedimentary Ore Deposits (Springer Verlag, New York, 1983).

Nalivkin, D.V., On conditions of formation of ancient faunally barren sequences of the western slope of the South Urals, VGRO, 1931, vol. 70, pp. 1100-1103.

Obruchev, V.A., Rudnye mestorozhdeniya (Ore Deposits), $2^{\text {nd }}$ Ed., Leningrad; ONTI. Glav. red. geol.-razved. i geodezich. Lit-ry, 1935.

Ovchinnikova, G.V., Kuznetsov, A.B., Krupenin, M.T., Vasil'eva, I.M., and Kaurova, O.K., $\mathrm{Pb}-\mathrm{Pb}$ age of the Bakal ore field Riphean Magnesite, Dokl. Earth Sci., 2018, vol. 481, no. 2, pp. 1040-1044.

Ovchinnikova, G.V., Kuznetsov, A.B., Vasil'eva, I.M., Gorokhov, I.M., Krupenin, M.T., Gorokhovskii, B.M. and Maslov, A.V., $\mathrm{Pb}-\mathrm{Pb}$ age and $\mathrm{Sr}$ isotopic characteristic of the Middle Riphean phosphorite concretions: the ZigazaKomarovo Formation of the South Urals, Dokl. Earth Sci., 2013, vol. 451, no. 2, pp. 798-802.

Parnachev, V.P., Rotar', A.F., and Rotar', Z.M., Srednerifeiskaya vulkanogenno-osadochnaya assotsiatsiya Bashkirskogo antiklinoriya (Middle Riphean Volcanogenic-Sedimentary Association of the Bashkir Anticlinorium), Sverdlovsk: UNTs AN SSSR, 1986. 103 s.

Pohl, W., Comparative geology of magnesite deposits and occurrences, Magnesite-Geology, Mineralogy, Geochemistry, Formation of Mg-Carbonates, Moeller, P., Ed., Monogr. Ser. Mineral Deposits, 1989, vol. 28, pp. 1-13.

Prochaska, W. and Krupenin, M.T., Evidence of inclusion fluid chemistry for the formation of magnesite and siderite deposits in the Southern Urals, Mineral. Petrol., 2013, vol. 107 , no. 1 , pp. 53-65.

Prochaska, W., Genetic concepts on the formation of the Austrian magnesite and siderite mineralizations in the Eastern Alps of Austria, Geologia Croatica, 2016, vol. 69, pp. 31-38.

Puchkov, V.N., Geologiya Urala i Priural'ya (aktual'nye voprosy stratigrafii, tektoniki, geodinamiki i metallogenii) (Geology of the Urals and Cis-Urals: Actual Problems of Stratigraphy, Tectonics, and Metallogeny), Ufa: DizainPoligrafServis, 2010.

Puchkov, V.N., Sergeeva, N.D., and Krasnobaev, A.A., Stratigraphic scheme of the Riphean stratotytpe of the South Urals, Geol. Izv. Otd. Nauk Zemle Prir. Res AN RB, 2017, vol. 23, pp. 3-26.

Radvanec, M., Grecula, P., and Zak, K., Siderite mineralization of the Gemericum superunit (Western Carpathians,
Slovakia): review and a revised genetic model, Ore Geol. Rev., 2004, vol. 24, nos. 3/4, pp. 267-298.

Redlich, K.A., Der steirische Erzberg. Bergbau Steiermarks, H. G. Leoben, 1916.

Savard, M.M., Sangster, D.F., and Burtt, M.D., Isotope geochemistry of sideritized host rocks, Walton Ba deposit, Kennetcook sub-basin, Nova Scotia, Canada, Econ. Geol., 1998, vol. 93, no. 6, pp. 834-844.

Semikhatov, M.A., Kuznetsov, A.B., and Chumakov, N.M., Isotope age of boundaries between the general stratigraphic subdivisions of the Upper Proterozoic (Riphean and Vendian) in Russia: the evolution of opinions and the current estimate, Stratigraphy. Geol. Correlation, 2015, vol. 23, no. 6, pp. 568-579.

Semikhatov, M.A., Kuznetsov, A.B., Maslov, A.V., Gorokhov, I.M., and Ovchinnikova, G.V., Stratotype of the Lower Riphean, the Burzyan Group of the Southern Urals: lithostratigraphy, paleontology, geochronology, Sr- and Cisotopic characteristics of its carbonate rocks, Stratigraphy. Geol. Correlation, 2009, vol. 17, no. 6, pp. 574-601.

Stratotip rifeya. Stratigrafiya i geokhronologiya (Riphean Stratotype. Stratigraphy and Geochronology), Moscow: Nauka, 1982.

Timeskov, V.A., Mineralogiya karbonatnykh rud $i$ vmeshchayushchikh ikh karbonatnykh porod Bakal'skogo zhelezorudnogo mestorozhdeniya na Yuzhnom Urale (Mineralogy of the Carbonate Ores and Host Carbonate Rocks of the Bakal Iron Ore Deposit, South Urals), Kazan': Kazan. Univ., 1963.

Varlakov, A.S., Metamorfizm v svyazi s diabazami v raione Bakal'skogo rudnogo polya (Metamorphism in Relation with Diabases in the Area of the Bakal Ore Field), Moscow: Nedra, 1967.

Yanitskii, A.L. and Sergeev, O.P., Bakal'skie zhelezorudnye mestorozhdeniya i ikh genesis (Bakl Iron Ores and their Genesis), Moscow: AN SSSR, 1962. 112 c.

Yardley, W.D. and Bodnar, R.J., Fluids in the continental crust, Geochem. Persp., 2014, no. 1, pp. 1-127.

Zaitseva, T.S., Kuznetsov, A.B., Gorozhanin, V.M., Gorokhov, I.M., Ivanovskaya, T.A., and Konstantinova, G.V., The lower boundary of the Vendian in the Southern Urals as evidenced by the $\mathrm{Rb}-\mathrm{Sr}$ age of glauconites of the Bakeevo Formation, Stratigraphy. Geol. Correlation, 2019, vol. 27, no. 5, pp. 573-587.

Zavaritskii, A.N., K voprosu o proiskhozhdenii zheleznykh rud Bakala (On Problem of the Origin of the Bakal Iron Ores), Moscow: AN SSSR, 1939.

Translated by A. Bobrov 